\title{
The architecture of long-lived fault zones: insights from microstructure and quartz lattice-preferred orientations in mylonites of the Median Tectonic Line, SW Japan
}

\author{
Thomas A. Czertowicz ${ }^{1 *}$ (D), Toru Takeshita ${ }^{1}$, Shun Arai ${ }^{2}$, Takafumi Yamamoto ${ }^{3}$, Jun-lchi Ando ${ }^{4}$, Norio Shigematsu ${ }^{5}$
} and Ko-Ichiro Fujimoto ${ }^{6}$

\begin{abstract}
We combine field mapping with quartz microstructure and lattice preferred orientations (LPO) to constrain the mechanisms and spatio-temporal distribution of deformation surrounding the Median Tectonic Line (MTL), SW Japan. In the study area, the MTL occurs either as a narrow gouge zone or as a sharp contact between hangingwall quartzofeldspathic mylonites to the north and footwall pelitic schists to the south. Along the northern margin of the MTL, there exists a broad zone of mylonitic rocks, overprinted by cataclastic deformation and a damage zone associated with brittle deformation. The mylonitic shear zone is dominated by coarse-grained protomylonite up to $\sim 100 \mathrm{~m}$ from the MTL, where fine-grained ultramylonite becomes dominant. We observe a systematic variation in quartz LPO with distance from the MTL. In protomylonites, quartz LPOs are dominantly Y-maxima patterns, recording dislocation creep by prism<a> slip at $\sim 500^{\circ} \mathrm{C}$. Closer to the MTL, we observe $R$ - and Z-maxima, and single and crossed girdles, reflecting dislocation creep accommodated by mixed rhomb<a> and basal<a> slip, likely under cooler conditions $\left(\sim 300^{\circ} \mathrm{C}-400^{\circ} \mathrm{C}\right)$. Some ultramylonite samples yield weak to random LPOs, interpreted to result from the influx of fluid into the shear zone, which promoted deformation by grainsize-sensitive creep. Following cooling and uplift, deformation became brittle, resulting in the development of a narrow cataclasite zone. The cataclasite was weakened through the development of a phyllosilicate foliation. However, healing of fractures strengthened the cataclasites, resulting in the development of anastomosing cataclasite bands within the protomylonite.
\end{abstract}

Keywords: Median tectonic line, LPO, EBSD, Quartz, Fault, Deformation, Cataclasite, Mylonite, Pressure solution, Fluid

\section{Introduction}

The distribution of deformed rocks within fault zones (fault zone architecture) provides a first-order control on the style (e.g., viscous creep vs. seismic rupture) and distribution of deformation (Sibson 1977, 1983; Holdsworth et al. 2001; Faulkner et al. 2010). The study of exhumed fault zones in the field allows characterisation of fault zone architecture (e.g., Chester et al. 1993; Schulz and Evans 1998) and can provide insights into temporal changes in the distribution of deformation (e.g., Imber et al. 1997; Niwa et al. 2009; Shigematsu et al. 2009). These

\footnotetext{
* Correspondence: thomasczertowicz@gmail.com

1 Department of Natural History Sciences, Hokkaido University, Sapporo 060-0810, Japan

Full list of author information is available at the end of the article
}

results can be used to model fluid flow in and around faults (e.g., Evans and Chester 1995; Caine et al. 1996; Wibberley and Shimamoto 2003), improve our understanding of earthquake rupture (e.g., Ishikawa et al. 2014; Rowe and Griffith 2015), and advance the recognition and interpretation of faults in geophysical datasets (e.g., Faulkner et al. 2008). Intraplate earthquakes typically nucleate in the mid-crust, close to the transition between frictional and viscous deformation (Scholz 1998). It has been suggested that the contrast in deformation mechanisms and rheology across this boundary could cause loading of seismogenic faults, and may therefore contribute to the initiation of seismic rupture (e.g., Iio et al. 2004; Okudaira and Shigematsu 2012); it is therefore critical to characterise the structure of fault 
zones at the depth of the frictional-to-viscous transition (FVT).

In this contribution, we aim to determine the architecture of the Median Tectonic Line in SW Japan from directly below the FVT to within the upper crust, using surface outcrops of the fault and surrounding fault rocks. We use quartz lattice preferred orientation (LPO) as a proxy for deformation conditions (stress, strain rate, and temperature) and as an indication of the width of the deforming zone during exhumation of the fault toward the FVT. We selected a study area in western Mie Prefecture where the MTL is well exposed and was not reactivated in the Quaternary, meaning that older structures from deeper crustal levels are well preserved (Figs. 1 and 2).

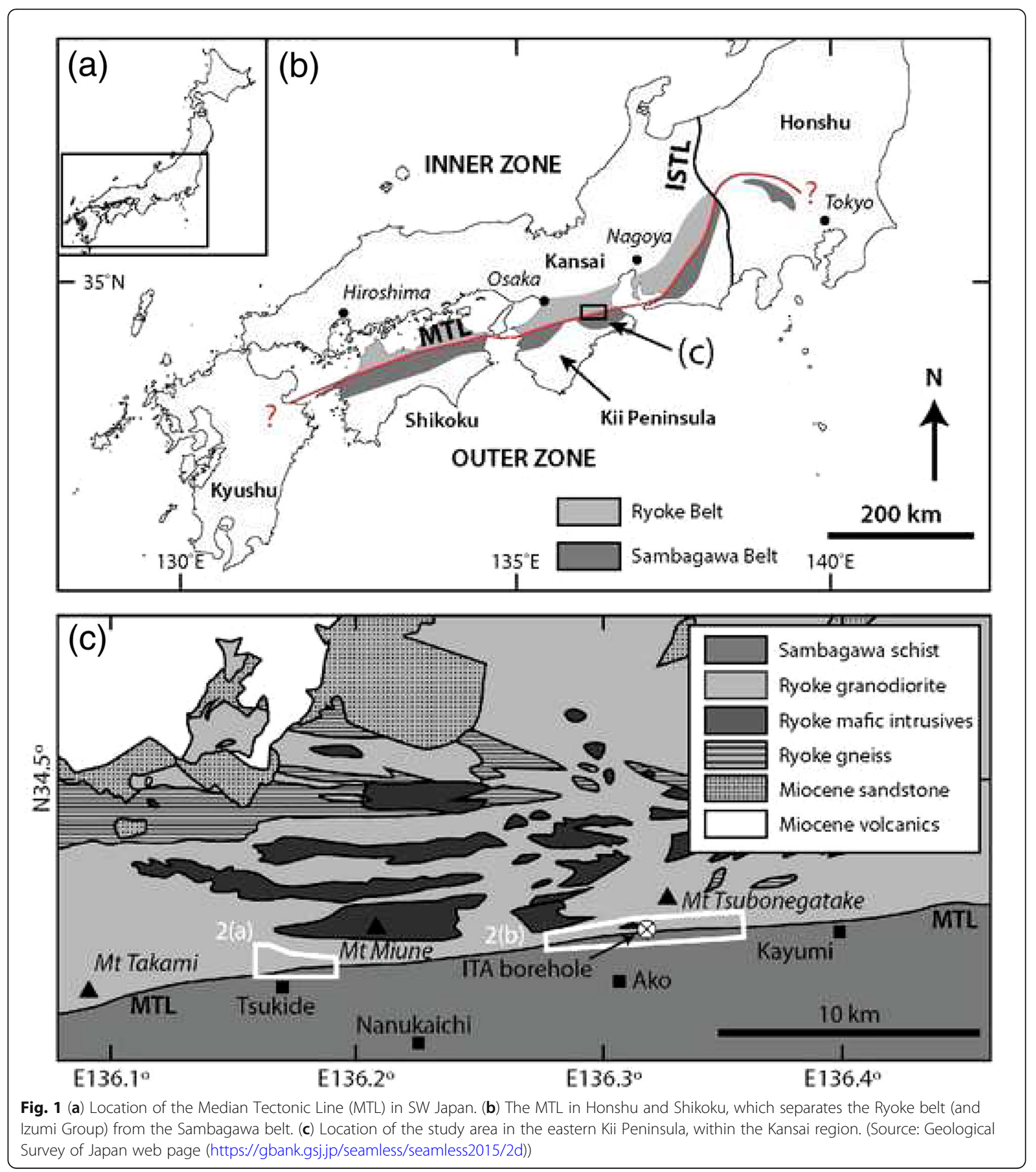




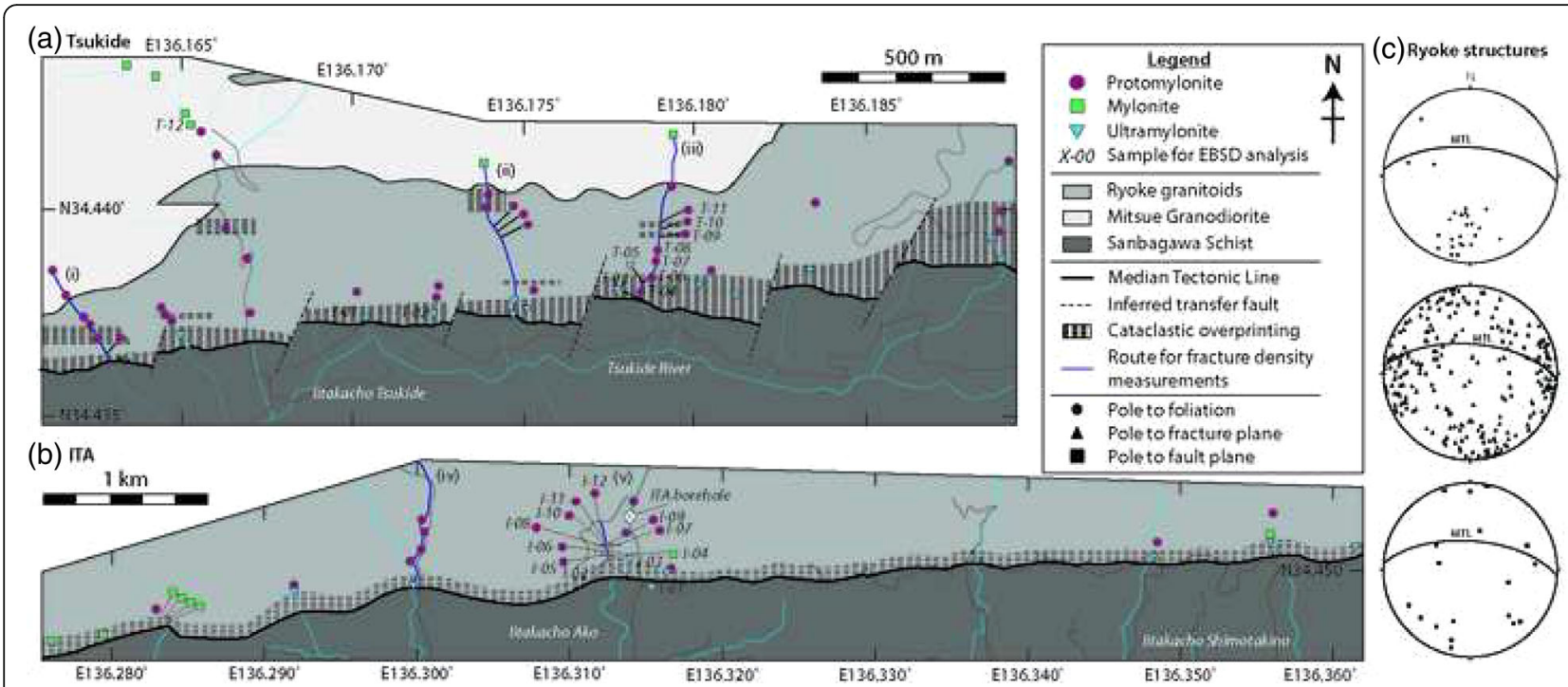

Fig. 2 Geological maps of the Tsukide (a) and Ako-Miyamae (b) areas showing the location of samples discussed in the text, and the orientation of foliations, fractures, and fault planes measured in the hanging wall of the MTL (c). The location of the MTL in the central section of (b) is after Shigematsu et al. (2012). The location of the boundary between the Hatai Tonalite and the Mitsue granodiorite is after Shigematsu (unpublished map)

Furthermore, several previous field studies and a borehole drilled into the MTL in the Iitaka region (referred to here as the ITA borehole) provide constraints on the tectonic history and deformation styles of the MTL in this area (e.g., Takagi 1985; Shimada et al. 1998; Wibberley and Shimamoto 2003; Jefferies et al. 2006a, b; Fukunari and Wallis 2007; Okudaira and Shigematsu 2012; Shigematsu et al. 2012; Takagi et al. 2012; Mori et al. 2015). We focus on two areas where the MTL is well exposed, centred around the previously-described Tsukide outcrop (see Wibberley and Shimamoto 2003) in the west (Fig. 2a) and the ITA borehole in the east (Fig. 2b).

\section{Geological setting}

The Median Tectonic Line (MTL), in SW Japan, is the longest exposed fault on the Japanese islands (strike length $>1000 \mathrm{~km})$ and has accommodated $\sim 200-1000 \mathrm{~km}$ of displacement since the Early Cretaceous (Fig. 1b; Ichikawa 1980; Takasu and Dallmeyer 1990; Sakashima et al. 2003). Recent seismic experiments indicate that the MTL dips to the north at $\sim 30-40^{\circ}$ and likely transects the entire crust (Ito et al. 1996, 2009; Sato et al. 2015). Here, we define the MTL as the boundary between two accretionary terranes, termed the Inner Zone (to the northwest, CarboniferousJurassic) and the Outer Zone (to the southeast; Jurassic-early Miocene, Fig. 1b; Ichikawa 1980). Within these terranes, the MTL juxtaposes the low-P/high-T Cretaceous Ryoke metamorphic belt, intruded by Cretaceous granitoids, against the high-P/low-T Cretaceous Sambagawa belt. These adjacent linear metamorphosed units have been interpreted as an example of a paired metamorphic belt (Miyashiro 1961), although this model is disputed (e.g., Brown 1998). To the southwest, the Upper Cretaceous Izumi Group marine sediments unconformably overlie the Ryoke belt and are juxtaposed against the Sambagawa belt across the MTL (Fig. 1b; Kubota and Takeshita 2008).

Throughout its tectonic history, the MTL has accommodated deformation under various stress fields and kinematic conditions (e.g., Ichikawa 1980; Famin et al. 2014). Deformation along the MTL began in the Late Cretaceous (before 83 Ma; Shimada et al. 1998; Kubota and Takeshita 2008) with left-lateral strike-slip motion related to oblique subduction at the trench (Ichikawa 1980; Takagi 1986; Shimada et al. 1998; Kubota and Takeshita 2008), accompanied by pull-apart basin formation and deposition of the Izumi Group (Hara et al. 1980; Miyata 1990; Noda et al. 2017). The MTL underwent normal-sense motion in the Palaeocene $(\sim 63-58 \mathrm{Ma})$, perhaps triggered by a reduction in convergence rate and/or subduction obliquity or by the balancing of crustal thickening (underplating) with gravitational collapse (Shibata et al. 1989; Kubota and Takeshita 2008). The Sambagawa and Ryoke belts were likely juxtaposed at this time (Kubota and Takeshita 2008). Kubota and Takeshita (2008) proposed that, during the Eocene to Oligocene (45-25 Ma), sinistral slip with a component of south-directed thrusting prevailed. In the middle Miocene, the MTL in the Shikoku region accommodated thrusting and normal-sense deformation (Takagi et al. 1992; Takeshita 1993; Fukunari and Wallis 2007). Thrusting also occurred in the Shikoku and Kinki regions in the Pleistocene (Okada and Sangawa 1978; Huzita 1980; Okada 1980). 
Westward of the Kii Peninsula, the MTL has undergone right-lateral slip since the Quaternary and remains active (Huzita 1980; Okada 1980, 2012; Sugiyama 1992). The mylonitic rocks examined in the present study were deformed during the "Kashio phase" (> $83 \mathrm{Ma}$ ), during which sinistral displacement prevailed along the marginal Ryoke shear zone (Shimada et al. 1998; Kubota and Takeshita 2008).

Correlation between outcrop and borehole data indicates that the MTL in the study area dips to the north at $\sim 56^{\circ}$ (Shigematsu et al. 2012). The Hatai Tonalite, a unit within the Ryoke Belt, crops out to the north of the MTL and was mylonitised during left-lateral deformation (Hayama et al. 1982; Takagi 1985; Nakajima 1994; Sakakibara 1996; Shimada et al. 1998; Suzuki and Adachi 1998; Okudaira et al. 2009). A wide mylonite zone $(\sim 1-2 \mathrm{~km})$, interpreted to represent the deep portion of the MTL, initially formed while the Hatai Tonalite was hot $\left(\sim 450{ }^{\circ} \mathrm{C}-500{ }^{\circ} \mathrm{C}\right)$, and deformation then localised under lower temperatures $\left(\sim 300{ }^{\circ} \mathrm{C}-400{ }^{\circ} \mathrm{C}\right)$ at c. $63-62 \mathrm{Ma}$ (Takagi 1986 ; Dallmeyer and Takasu 1991; Michibayashi and Masuda 1993; Yamamoto 1994; Sakakibara 1996; Shimada et al. 1998). Brittle deformation overprinted the mylonites at shallow crustal levels, resulting in the development of breccia, cataclasite, and fault gouge. Previous workers have suggested that the formation of mica-defined foliations in the cataclasites resulted in significant weakening of the MTL through the promotion of pressure-solution-assisted frictional-viscous flow (e.g., Jefferies et al. 2006a, b).

\section{Methods/Experimental}

\section{Fieldwork and sample preparation}

During two, two-week field excursions, we mapped the MTL in the Ako-Miyamae and Tsukide regions, focussing on the zone of mylonitic rocks to the north of the MTL. We systematically measured the orientations of foliations, lineations, fractures, fault planes, and fold axes. Samples collected from the field area were prepared as polished thin sections, which were analysed using a polarising microscope to determine mineralogy and microstructural relationships.

\section{Fracture measurements}

To constrain the width of the damage zone to the north of the MTL, we measured the abundance of fractures along approximately $\mathrm{N}-\mathrm{S}$ transects in river valleys with good exposure. We measured fractures where outcrop was accessible, using the circular intercept method of Mauldon et al. (2001) and Rohrbaugh Jr. et al. (2002). This method reduces bias related to the orientation and length distributions of fractures and has been shown to provide reliable data when applied to geological fracture sets (Watkins et al. 2015). We plot cumulative fracture counts, as recommended by Choi et al. (2016), because variations in fracture densities are represented by changes in slope, which are readily identifiable, allowing an accurate determination of damage zone width.

\section{Classification of samples}

To characterise the degree of brittle fragmentation and crushing, we follow Takagi et al. (2012) in defining four groups based on their degree of cataclasis (Table 1):

1. Uncrushed rocks. Lack evidence of pulverisation and contain less than five fractures or veins within a single thin section.

2. Slightly crushed rocks. Lack brecciation but contain more than five fractures or veins within a single thin section.

3. Moderately crushed rocks. Evidence of partial brecciation/pulverisation $(<80 \%)$ and the development of numerous fractures/veins.

4. Intensely crushed rocks. Thin sections are dominated $(>80 \%)$ by brecciated/pulverised material.

\section{EBSD analysis}

For EBSD analysis, we selected 12 mylonitic samples (Table 1) from the Tsukide area. Nine samples come from a $\sim \mathrm{N}-\mathrm{S}$-trending river valley that intersects the MTL, two ultramylonite samples were collected from close to the MTL in other river valleys, and one sample was collected far from the MTL, within a band of mylonite (Fig. 2a). In the Ako-Miyamae region, we selected 12 samples (Table 1) from a river valley oriented approximately $\mathrm{N}-\mathrm{S}$, close to the ITA borehole. Samples were collected where exposure permitted, resulting in a profile extending $\sim 100-400 \mathrm{~m}$ northward from the MTL (Fig. 2b).

Thin sections for EBSD analysis were cut perpendicular to the foliation, where possible, and polished using diamond paste, followed by colloidal silica. EBSD analysis was conducted on carbon-coated samples in a JEOL JIB-4600F/HKD field-emission gun scanning electron microscope (FEG-SEM) at a voltage of $15 \mathrm{kV}$ and a working distance of $\sim 25 \mathrm{~mm}$ at Hokkaido University, Japan. EBSD patterns were measured by an Oxford Instruments detector and indexed and processed using the Oxford Instruments Aztec software package.

Reduction of noise in the EBSD data was performed using the HKL Channel 5 software package. Pixels with no solution were reduced using a five-neighbour extrapolation, and "wild spikes" (isolated pixels of 
Table 1 Summary of Ryoke mylonite samples analysed by EBSD and their measured quartz LPO and recrystallised grain size

\begin{tabular}{|c|c|c|c|c|c|}
\hline $\begin{array}{l}\text { Sample } \\
\text { name }\end{array}$ & $\begin{array}{l}\text { Northward distance } \\
\text { from MTL }(m)\end{array}$ & Lithology & $\begin{array}{l}\text { Cataclasis } \\
\text { classification }\end{array}$ & Quartz [c]-axis fabric & $\begin{array}{l}\text { Mean recrystallised } \\
\text { grain size }(\mu \mathrm{m})\end{array}$ \\
\hline \multicolumn{6}{|l|}{ Tsukide } \\
\hline T-01 & 14 & Ultramylonite & C & $R$-maximum \& type-l crossed girdle & 6.8 \\
\hline T-02 & 20 & Ultramylonite & C & $R$-maximum \& type-l crossed girdle & 11.2 \\
\hline T-03 & 22 & Mylonite & $\mathrm{D}$ & Random \& R-maximum & 19.2 \\
\hline T-04 & 36 & Protomylonite & B & Z-maximum & 16.1 \\
\hline T-05 & 50 & Ultramylonite & C & Random \& Y-maximum & 3.6 \\
\hline T-06 & 78 & Protomylonite & B & $Y$-maximum \& single girdle & 20.5 \\
\hline T-07 & 122 & Protomylonite & B & $Y$-maximum & 18.5 \\
\hline $\mathrm{T}-08$ & 162 & Protomylonite & C & $Y$-maximum, $R$-maximum, \& single girdle & 17.8 \\
\hline T-09 & 191 & Protomylonite & B & $Y$-maximum \& $R$-maximum & 29.7 \\
\hline $\mathrm{T}-10$ & 222 & Protomylonite & $\mathrm{D}$ & $Y$-maximum, single girdle & 5.3 \\
\hline $\mathrm{T}-11$ & 248 & Protomylonite & $\mathrm{D}$ & $Y$-maximum \& $R$-maximum & 15.2 \\
\hline$T-12$ & 641 & Mylonite & A & $Y$-maximum & 142.0 \\
\hline \multicolumn{6}{|c|}{ Ako-Miyamae } \\
\hline A-01 & 60 & Ultramylonite & $\mathrm{D}$ & $R$-maximum & 7.1 \\
\hline $\mathrm{A}-02$ & 109 & Ultramylonite & $\mathrm{D}$ & Random & 3.8 \\
\hline A-03 & 117 & Ultramylonite & C & Random \& single girdle & 5.5 \\
\hline $\mathrm{A}-04$ & 124 & Mylonite & $\mathrm{D}$ & $R$-maximum & 14.8 \\
\hline $\mathrm{A}-05$ & 132 & Protomylonite & A & $R$-maximum \& type-l crossed girdle & 36.7 \\
\hline A-06 & 139 & Protomylonite & C & $Y$-maximum & 38.2 \\
\hline $\mathrm{A}-07$ & 147 & Protomylonite & B & $Y$-maximum & 49.0 \\
\hline $\mathrm{A}-08$ & 154 & Protomylonite & $C$ & $Y$-maximum & 27.3 \\
\hline A-09 & 161 & Protomylonite & $C$ & $Y$-maximum & 33.4 \\
\hline$A-10$ & 192 & Protomylonite & $\mathrm{D}$ & $Y$-maximum & 35.8 \\
\hline$A-11$ & 197 & Protomylonite & $B$ & $Y$-maximum & 35.9 \\
\hline$A-12$ & 363 & Protomylonite & A & $Y$-maximum & 43.4 \\
\hline
\end{tabular}

inconsistent orientation) were removed. Further processing and analysis of the data were conducted in the MTEX toolbox for MATLAB ${ }^{\text {Tw }}$ (Bachmann et al. 2010). Contoured pole figures were produced from an ODF calculated at a halfwidth of $10^{\circ}$ and were contoured at $1^{\circ}$ intervals. As many of the analysed samples are mylonitic clasts within cataclasites, their sample reference frame (i.e., foliation and lineation) was unknown during analysis. To rotate the acquired pole figures into the standard orientation used for structural analysis (i.e., lineation plotting E-W and the pole to foliation plotting $\mathrm{N}-\mathrm{S}$ ), we analysed the internal symmetry of the pattern and rotated it to the orientation that was most consistent with LPO produced by the dominant slip systems in quartz (see Schmid and Casey 1986). To confirm that the chosen rotation was correct, we analysed the misorientation amongst grains and subgrains (misorientation angle $>2^{\circ}$ ). For boundaries dominated by edge dislocations, misorientation axes are expected to cluster around the normal to a plane containing the slip direction and the pole to the slip plane (e.g., toward the $<\mathrm{c}>$ direction for slip parallel to the <a> axis along prism planes (prism <a> slip)) (see Bestmann and Prior 2003). To quantify the strength and shape of quartz LPOs, we calculated the eigenvalues of the orientation tensor (Woodcock 1977) derived from EBSD data. Fabric strength was quantified using the "intensity" parameter of Lisle (1985), defined as:

$$
I=\frac{15}{2} \sum_{i=1}^{3}\left(S_{i}-\frac{1}{3}\right)^{2}
$$

where $I=$ intensity and $S_{i}=$ eigenvalues. This parameter produces a number between 0 and 5 , with 0 indicating a uniform distribution and 5 representing a single cluster fabric. This method was preferred over the conventional $\mathrm{J}$ - and $\mathrm{M}$-indices as it is not sensitive to differences in sample size, permitting an unbiased comparison between fabrics in various samples. Cluster, girdle, and uniform (referred to as "random" by Vollmer (1990)) components 
of LPOs were calculated using the acquired eigenvalues and the following parameters:

$$
\begin{aligned}
& \text { Cluster }=S_{1}-S_{2}, \\
& \text { Girdle }=2\left(S_{2}-S_{3}\right), \\
& \text { Uniform }=3 S_{3}
\end{aligned}
$$

where $S_{1-3}$ represent the eigenvalues of the normalised orientation tensor (Vollmer 1990).

For grain size analysis, we defined grains using MTEX as being separated by boundaries representing at least $10^{\circ}$ misorientation. To reduce uncertainty in the calculated grain sizes, we removed grains with less than five measured pixels or that bordered the edge of the maps. Presented grain sizes are circle-equivalent diameters. We follow the method presented by Cross et al. (2017) to separate relict and recrystallised grains. We describe quartz microstructures in terms of aspect ratio (grain length/grain width) and shape factor (grain perimeter/ ellipse-equivalent perimeter; see Takeshita and ElFakharani 2013).

\section{Results}

\section{Outcrop observations}

Figure $2 \mathrm{a}, \mathrm{b}$ shows the distribution of fault rocks around the MTL in the study area. The Sambagawa schist crops out to the south of the MTL, within the footwall. We observe a progressive increase in accumulated damage in the schist within $\sim 150 \mathrm{~m}$ of the MTL. The rocks are dominantly pelitic, host abundant quartz veins, and dip steeply to the north. Within the schist, numerous brittle, semi-brittle, and ductile deformation features are observed (Fig. 3a, b). Minor faults developed within the schist are

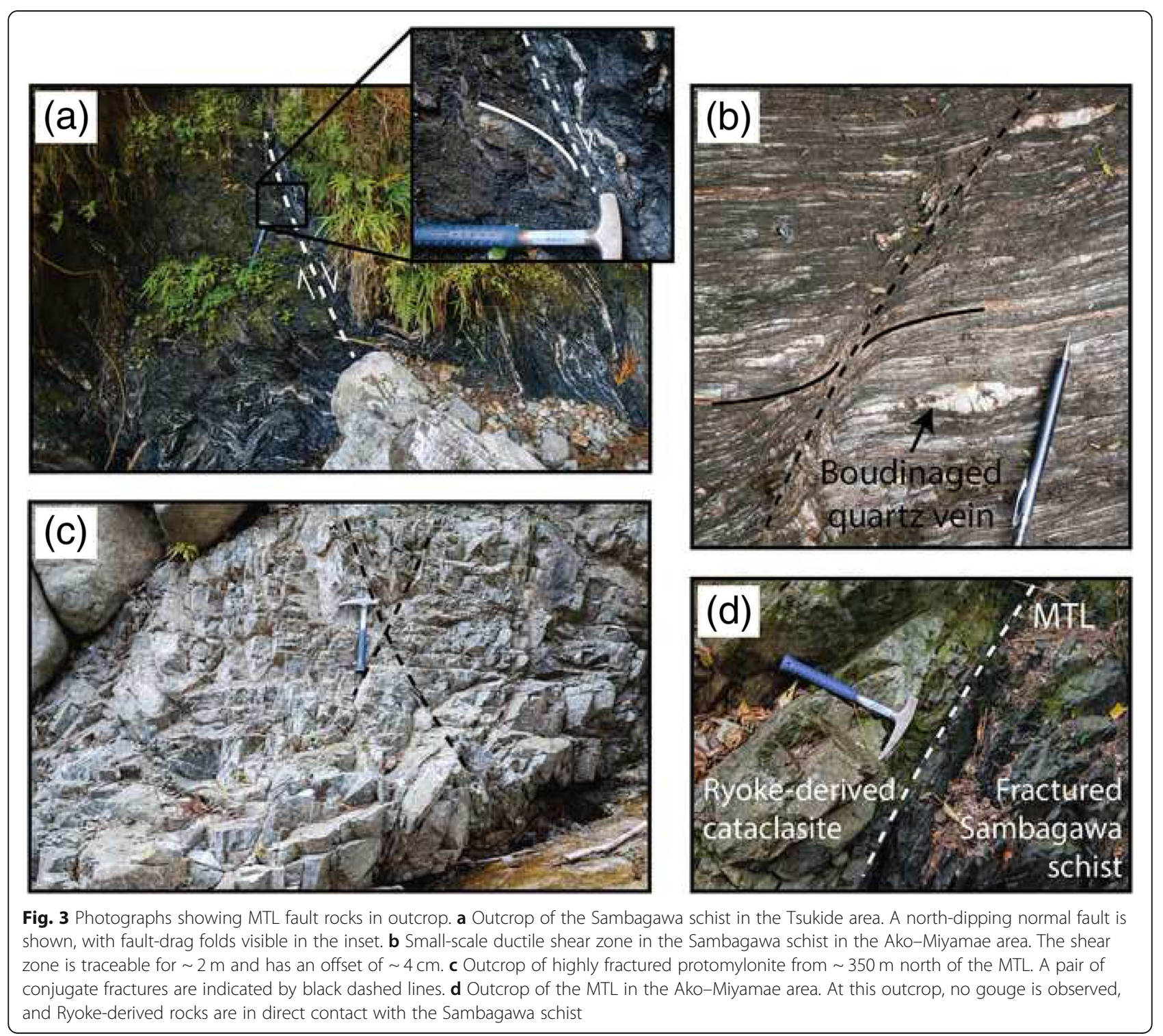


dominantly sub-parallel to the MTL and commonly record normal-sense motion (Fig. 3a). In addition, we observed many small folds, some of which may be related to slip on associated normal-sense minor faults.

The Ryoke granitoid is dominantly mylonitised and foliated and is crosscut by numerous veins and fractures. We identified a broad band of coarse-grained mylonitic rock at $\sim 600 \mathrm{~m}$ from the MTL in the Tsukide area, within the Mitsue Granodiorite (referred to here as the "exterior mylonite"; Fig. 2a). Within $\sim 200 \mathrm{~m}$ of the MTL, the rocks become highly fractured and veined and are interpreted as cataclasites. However, cataclasis is not restricted to rocks adjacent to the MTL, and anastomosing bands of highly fractured rocks are observed up to $350 \mathrm{~m}$ north of the MTL (Fig. 3c). Similarly, rocks classified as moderately and intensely crushed (based on thin section observations) occur up to $250 \mathrm{~m}$ from the MTL (groups C and D; Table 1). Samples more distal to the MTL are uncrushed (group A; Table 1).

Foliations in the cataclasites and protomylonites dip, on average, $51^{\circ}$ toward $015^{\circ}$ (Fig. 2c). Fractures within the Ryoke mylonites display a wide range of orientations with a weak preferred orientation close to vertical, striking $\mathrm{N}-\mathrm{S}$ and $\mathrm{E}-\mathrm{W}$ (Fig. 2c). Many fractures are barren; however, others contain precipitates of dominantly carbonate, quartz, and chlorite. Faults within the Ryoke rocks show no preferred orientation (Fig. 2c). The MTL itself is exposed in several places within the field area. In some locations, a sharp contact, directly juxtaposing Ryoke- and Sambagawa-derived rocks, is observed (dipping $\sim 60^{\circ}$ to the north; Fig. 3d), whereas in other areas, a zone of $\sim 10 \mathrm{~cm}$ of black fault gouge is developed along the lithological contact.

\section{Damage zone thickness}

The locations of fracture measuring profiles are indicated in Fig. 2a, b, and the results of the measurements are shown in Fig. 4. We identify clear changes in slope in four of the five cumulative fracture profiles and estimate the damage zone width (in the hanging wall only) as varying between 102 and $268 \mathrm{~m}$ (Fig. 4). The data from profile (ii) are more complex and show a steep trend up to distances of $\sim 400 \mathrm{~m}$, with a zone of lower fracture density between $\sim 100-200 \mathrm{~m}$. In conclusion, the damage zone within the hanging wall of the MTL in the study area displays considerable along-strike variation, ranging from $\sim 100$ to $300 \mathrm{~m}$. Correction for the dip of the MTL $\left(56^{\circ}\right.$; Shigematsu et al. 2012) produces a true thickness for the damage zone of $85-222 \mathrm{~m}$.

\section{Thin section observations}

Thin section observations of Ryoke samples reveal an increase in the proportion of recrystallised grains

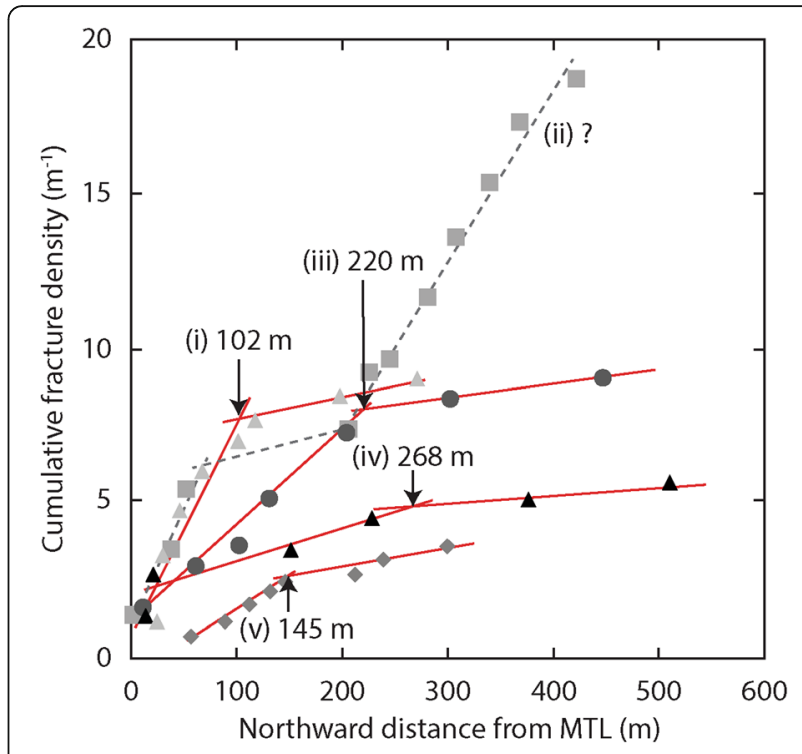

Fig. 4 Macrofracture densities measured within the Ryoke mylonites in the hanging wall of the MTL. Profile locations are indicated in Fig. $2 a, b$. The width of the damage zone associated with the MTL is estimated using the change in slope of cumulative fracture counts

toward the MTL. Protomylonite (recrystallised grains $<50 \%$; Sibson 1977) is dominant far from the MTL, whereas entirely recrystallised, very fine-grained ultramylonite (recrystallised grains $>90 \%$; Sibson 1977) occurs closer to the fault. The width of the ultramylonite zone (measured $\mathrm{N}-\mathrm{S}$ ) varies along strike between 0 and $\sim 100 \mathrm{~m}$ but is typically $\sim 50 \mathrm{~m}$ thick (Fig. 2a, b). Mylonitic rocks (recrystallised grains = 50-90\%; Sibson 1977) are rarely observed in the study area, and the transition from protomylonite to ultramylonite is abrupt. Mylonites are, however, found locally in isolated patches along the MTL, as well as within the "exterior mylonite" (Fig. 2a, b).

Protomylonite samples contain large porphyroclasts of plagioclase that have commonly undergone extensive sericitisation (Fig. 5a). In some samples (likely those with a more mafic bulk composition), former hornblende porphyroclasts have been replaced by coarse-grained dark blue chlorite (cf. Takagi 1985; Kaneko et al. 2017). Mylonitic samples are typically overprinted by cataclasis and contain $<50 \%$ feldspar porphyroclasts. Samples from the exterior mylonite zone in the Tsukide area (Fig. 2a) contain coarse recrystallised quartz grains, lacking undulatory extinction and subgrain structures, separated by lobate, interleaving grain boundaries (arrows in Fig. 5b). Ultramylonitic samples have extremely fine grain sizes, making thin section observations difficult. They have a strong foliation defined by alternations of muscovite- and quartz \pm feldspar-rich bands (Fig. 5c). 

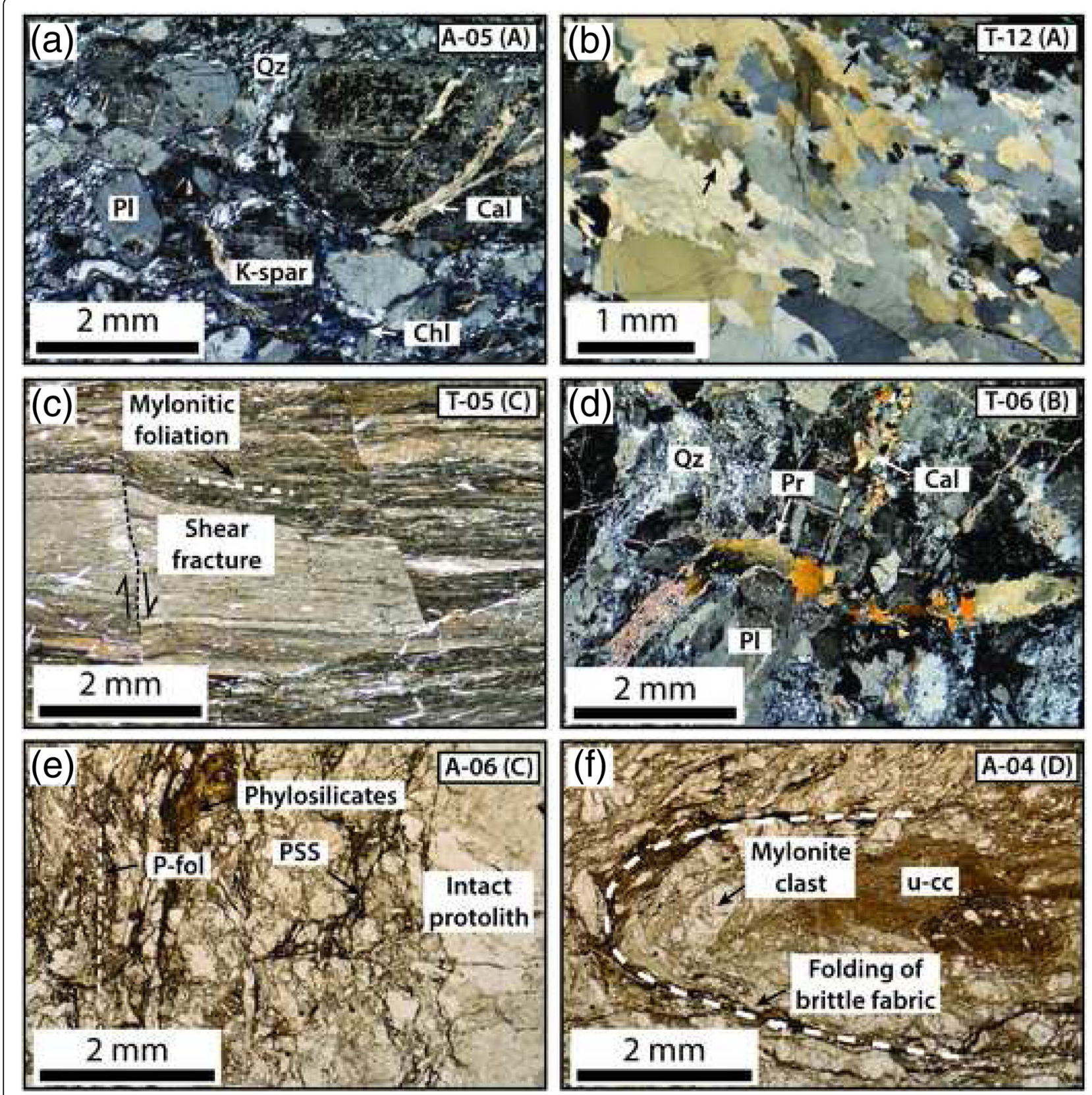

Fig. 5 Ryoke-derived fault rocks in thin section. Letter after sample name indicates the degree of cataclasis (see text). a Lightly fractured Ryoke protomylonite sample containing altered plagioclase (PI) and K-feldspar (K-spar) porphyroclasts wrapped by a matrix of recrystallised quartz (Qz) and chlorite (Chl). Fractures within feldspar porphyroclasts are filled with calcite (Cal) (cross-polarised light). b Exterior mylonite sample showing characteristic coarse recrystallised quartz grains, separated by lobate grain boundaries (arrows; cross-polarised light)). $\mathbf{c}$ Ultramylonite sample that has undergone limited fragmentation and slip along shear fractures (plane-polarised light). d Protomylonite sample cut by late-stage coarsegrained prehnite (Pr)-calcite veins (cross-polarised light). e Cataclasite displaying progressive granulation and development of a phyllosilicate foliation (P-fol) from right to left. PSS pressure-solution seam (plane-polarised light). f Cataclasite displaying isoclinal folding of a cataclastic foliation, with ultra-cataclasite (u-cc) developed in the fold hinge (plane-polarised light)

Veins are variably developed in the analysed samples, correlate with the degree of cataclasis, and commonly crosscut porphyroclasts and recrystallised matrix (Fig. 5a, c, d). Vein fills include calcite (Fig. 5a), chlorite, quartz, white mica, and prehnite (Fig. 5d; cf. Kaneko et al. 2017). Cataclastic samples contain clasts of ultramylonite and show evidence for fracturing, granulation, clast rotation, and diffusive mass transfer. The matrix in cataclasites is typically fine grained and phyllosilicate-rich (Fig. 5e). In some 
samples, zones of almost pure cataclastic matrix are observed and are classified as ultracataclasites (Fig. 5f) (Sibson 1977). In others, phyllosilicate minerals are aligned and define a cataclastic foliation (P-fol; Fig. 5e), and in one sample from the Ako-Miyamae area, we observe folding of such a fabric (Fig. 5f).

\section{Quartz microstructures-Tsukide area}

Variation in quartz microstructure in the Tsukide area is independent of distance from the MTL, with aspect ratios (AR) and shape factors (SF) ranging from 1.53 to 1.68 and 1.12 to 1.46 , respectively (Fig. 6a). Sample T-12 (collected from the exterior mylonite zone, $641 \mathrm{~m}$ from the MTL) contains coarse relict $(327 \mu \mathrm{m})$ and recrystallised grains $(142 \mu \mathrm{m})$ (Fig. 7a). However, recrystallised grain size in the other samples does not vary systematically with distance from the MTL, ranging from 4 to
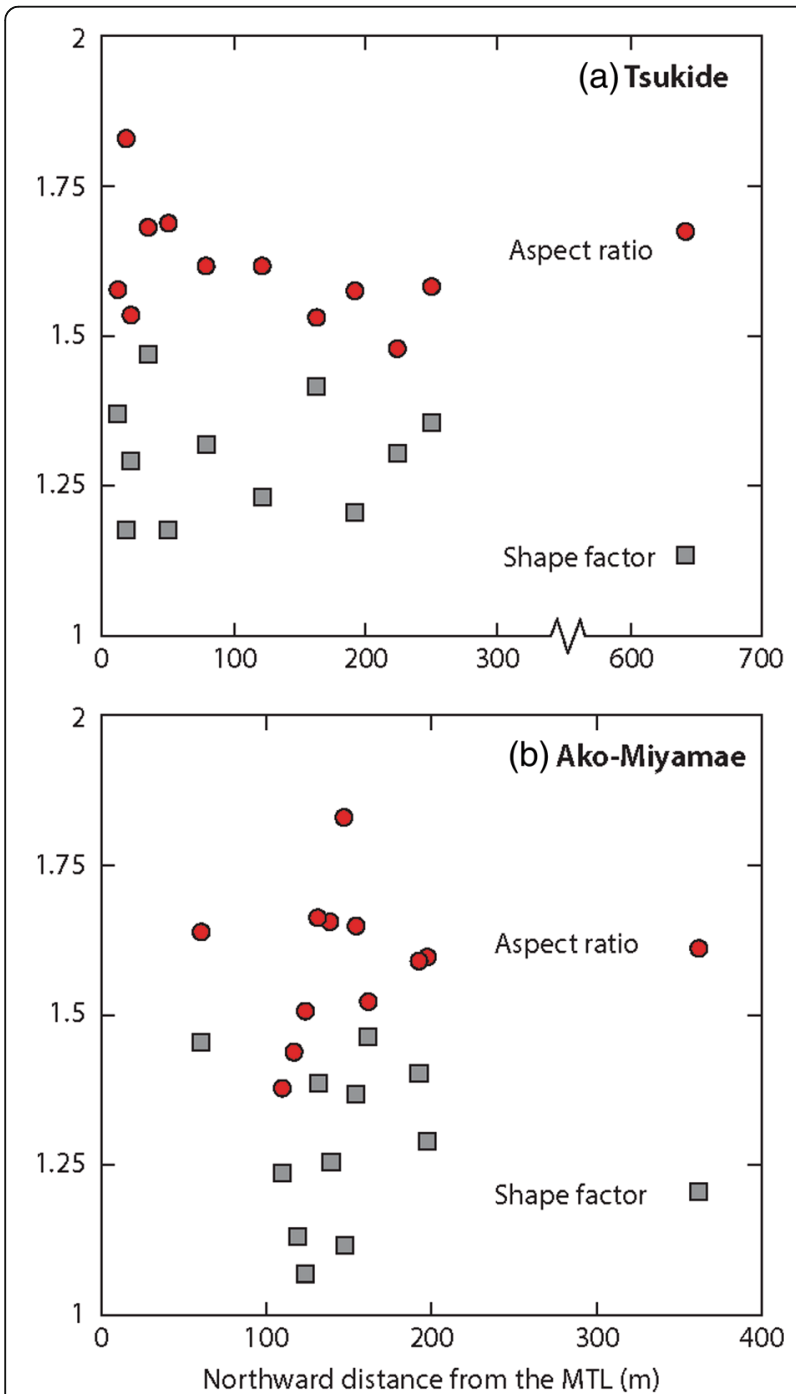

Fig. 6 Variation in aspect ratio and shape factor with distance from the MTL in the Tsukide (a) and Ako-Miyamae (b) areas
$30 \mu \mathrm{m}$ (Fig. 9a). We observe fine recrystallised grain sizes far from the MTL $(222 \mathrm{~m}$ ) (Figs. 7b and 9a) as well as closer to the fault (50 and $14 \mathrm{~m}$; Fig. 7c). Samples with moderately large recrystalised grains, which contain elongate $(\mathrm{AR}=1.68)$ relict grains with complex grain boundaries $(\mathrm{SF}=1.46)$, can be found up to $36 \mathrm{~m}$ from the MTL (e.g., T-04; Fig. 7d).

Samples far from the MTL ( $>78 \mathrm{~m}$ ) yield quartz LPOs with $[c]$-axes clustered parallel to the $Y$ structural direction, and $<$ a $>$ axes concentrated within the $X Z$ plane in three-point concentrations, approximating a single crystal texture ( $Y$-maximum; Fig. 9a). However, several samples (T-06 and T-08-11) also contain aggregates that yield single girdle patterns. Sample T-04, collected from $36 \mathrm{~m}$ north of the MTL, displays a concentration of $[c]$-axes around the $Z$ direction, and three-point concentrations of <a> axes within the $X Y$ plane, approximating a single crystal orientation ( $Z$ maximum; Fig. 9a), which is similar to fabrics described by Okudaira and Shigematsu (2012) for ITA borehole samples from close to the MTL. Random fabrics are observed in samples from 22 (T-03) and $50 \mathrm{~m}$ (T-05) from the MTL (Fig. 9a), although both samples contain areas that yield weak LPOs. The two samples collected closest to the MTL (T-01 and T-02) preserve type-I crossed girdles (Schmid and Casey 1986) with maxima around poles to the rhomb planes ( $R$-maxima; Fig. 9a). LPO intensity is generally not correlated with distance from the MTL, although low-intensity LPOs dominate within $22 \mathrm{~m}$ of the MTL (Fig. 10a). Trends in LPO components are also unclear, although we observe an increase in the proportion of girdle fabrics toward the MTL (Fig. 10b). The exterior mylonite sample has a strong $Y$-maximum fabric dominated by a point component (Fig. 10a, b).

\section{Quartz microstructures-Ako-Miyamae area}

In contrast to the Tsukide area, we observe a systematic variation in quartz microstructure with distance from the MTL (Fig. 8a-d). Far from the MTL (>160 m), protomylonites contain roughly equant quartz grains with AR of 1.52-1.61 and mean recrystallised grain sizes of 33-43 $\mu \mathrm{m}$ (Figs. 6b, 8a and 9b). Grain boundaries are generally curved and show a moderate degree of complexity with mean SF of 1.20-1.46 (Fig. 6b).

Closer to the MTL ( 155-130 m), quartz grains become elongate ( $\mathrm{AR}=1.64-1.83)$ and grain boundaries are less complex (SF = 1.11-1.38; Figs. 6b and 8b). Mean recrystallised grain sizes of these samples range from 38 to $49 \mu \mathrm{m}$, similar to samples containing equant grains (Fig. 9b). In contrast, at $\sim 130 \mathrm{~m}$ from the MTL, recrystallised grain size (4-15 $\mu \mathrm{m})$, AR (1.37-1.50), and SF (1.06-1.23) are all observed to decrease rapidly (Figs. 6b, $8 \mathrm{c}$ and $9 \mathrm{~b}$ ). However, sample I-01, located $60 \mathrm{~m}$ from the MTL, contains coarser grains with complex boundaries $(\mathrm{AR}=1.63, \mathrm{SF}=1.45$; Figs. 6b, 8d and 9b). In summary, elongate quartz 


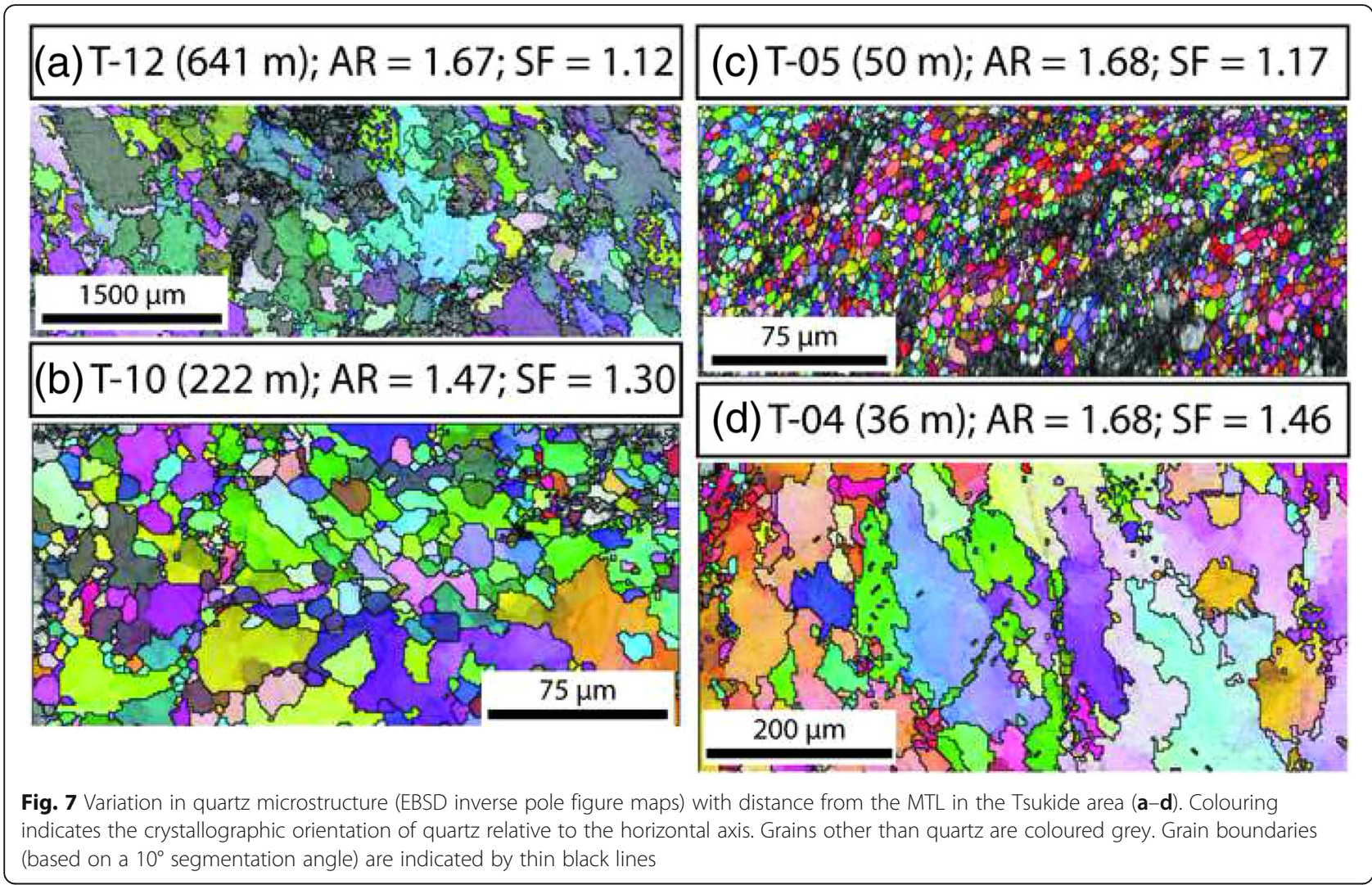

grains with simple grain boundaries occur at $\sim 150 \mathrm{~m}$ from the MTL, with equant grains dominating closer and further from the fault (excluding sample I-01). At distances closer than $150 \mathrm{~m}$, recrystallised grain size decreases rapidly to a minimum of $4 \mu \mathrm{m}$.

In the Ako-Miyamae area, quartz LPO and recrystallised grain size are well correlated with distance from the MTL (Fig. 9b). At large distances from the fault ( $150-400 \mathrm{~m}$ ), coarse-grained quartz yields $Y$-maximum fabrics (I-06-12). Between $\sim 150$ and $115 \mathrm{~m}$ from the MTL, we observe a decrease in grain size and a change in $[c]$-axis distribution to type-I crossed girdles with a $Y$-maximum component (I-05), single girdle (I-03), and type-I crossed girdles with $R$-maxima (I-04) fabrics (Fig. $9 \mathrm{~b})$. These fabric types are gradational and represent varying concentrations of $[c]$-axes within the $Y Z$ plane. Between $\sim 120$ and $100 \mathrm{~m}$ from the MTL, we observe fine recrystallised quartz grains with weak to random LPOs (I-02; Fig. 9b). However, the ultramylonite sample closest to the MTL (I-01) yields an $R$-maximum fabric (Fig. 9b). The strength of quartz LPOs within the AkoMiyamae profile is observed to decrease toward the MTL, with a minimum at $109 \mathrm{~m}$ reflecting auniform LPO (Fig. 10c). With decreasing distance from the MTL, fabrics become less clustered, while girdle and uniform contributions increase (Fig. 10d). A distinct change in gradient is observed at $\sim 150 \mathrm{~m}$, approximately the same distance at which mean recrystallised grain size is observed to decrease (Figs. 9b and 10c, d).

\section{Discussion}

Deformation temperature

Quartz microstructures (Hirth and Tullis 1992; Passchier and Trouw 1998; Stipp et al. 2002) and slip systems (Mainprice et al. 1986; Schmid and Casey 1986; Takeshita et al. 1999; Little et al. 2013) are sensitive to temperature and may be used to constrain the prevailing conditions during deformation. Many of the investigated samples yield strong LPOs and contain relict grains with significant intragranular distortion, indicative of deformation accommodated by dislocation creep. Although the effects of temperature on quartz LPO development are not well quantified (see Toy et al. 2008), many studies report a general dominance of prism<a> slip under upper greenschist - to amphibolite-facies conditions, and mixed $<a>$ slip (prism-, rhomb-, and/or basal<a $>$ slip) under lower greenschist conditions (e.g., Takeshita et al. 1999; Little et al. 2013). At temperatures above $\sim 650$ ${ }^{\circ} \mathrm{C}$, prism $<\mathrm{c}>$ becomes the dominant slip system in quartz (Mainprice et al. 1986; Law 1990).

Protomylonite samples from $>\sim 100 \mathrm{~m}$ north of the MTL dominantly preserve $Y$-maximum LPOs, characteristic of 


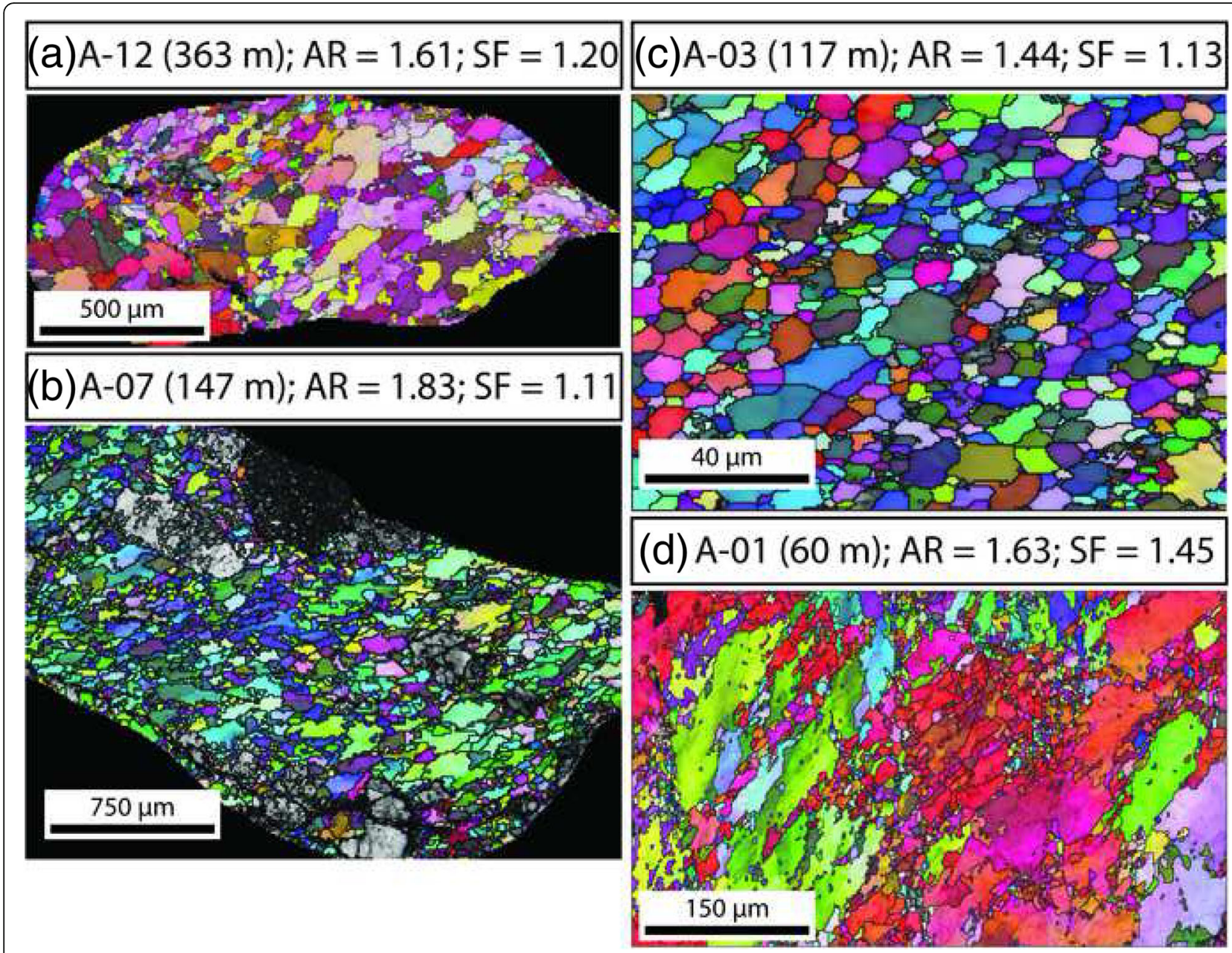

Fig. 8 Variation in quartz microstructure (EBSD inverse pole figure maps) with distance from the MTL in the Ako-Miyamae area (a-d). See Fig. 7 for an explanation of the colour scheme

slip on the prism<a $>$ system, likely corresponding to deformation temperatures of $\sim 350^{\circ} \mathrm{C}-550^{\circ} \mathrm{C}$ (Mainprice et al. 1986; Schmid and Casey 1986; Okudaira et al. 1995). This estimate is further constrained by the observation of subgrain structures and a large proportion of low angle boundaries, suggesting recovery by subgrain rotation recrystallisation (SGR) at temperatures between $\sim 350^{\circ} \mathrm{C}$ and $450^{\circ} \mathrm{C}$ (Stipp et al. 2002), and the presence of sheared chlorite after biotite within some protomylonite samples, suggesting deformation within the greenschist facies. The exterior mylonite (Fig. 2a) also records slip along the prism $<$ a $>$ system, but lacks chlorite, and contains quartz grains that lack internal distortion, surrounded by lobate grain boundaries, suggesting they recrystallised by grain boundary migration (GBM), consistent with deformation under higher temperatures $\left(\sim 450^{\circ} \mathrm{C}-650^{\circ} \mathrm{C}\right.$; Stipp et al. 2002) than the protomylonite samples. Closer to the MTL, samples yield $R$-maxima, $Z$-maximum, and type-I crossed girdle fabrics, suggesting that deformation in these samples was accommodated by mixed basal, rhomb, and prism $<$ a $>$ slip, likely under lower greenschist-facies temperatures (Takeshita and Wenk 1988; Takeshita et al. 1999).

\section{Differential stress and strain rate}

To constrain the differential stress within the MTL fault zone during formation of the mylonitic rocks, we constructed quartz deformation mechanism maps. Dislocation creep may be represented by the flow law proposed by Hirth et al. (2001):

$$
\dot{\varepsilon}=A f_{\mathrm{H}_{2} \mathrm{O}}^{m} \sigma^{n} e^{\frac{-Q}{R T}}
$$

where $\dot{\varepsilon}$ is the strain rate $\left(s^{-1}\right), A$ is a material parameter $\left(\log A=-11.2 \mathrm{MPa}^{-4} \mathrm{~s}^{-1}\right), f_{\mathrm{H}_{2} \mathrm{O}}$ is the water fugacity, $m$ is the water fugacity exponent (1), $\sigma$ is differential stress (MPa), $n$ is the stress exponent (4), $Q$ is the activation energy $\left(135 \mathrm{kJmol}^{-1}\right), R$ is the universal gas constant $(8.314$ $\mathrm{Jmol}^{-1} \mathrm{~K}^{-1}$ ), and $T$ is temperature (K). We calculated water fugacity using JavaScript code hosted at http:// www.geo.umn.edu/people/researchers/withe012, which 


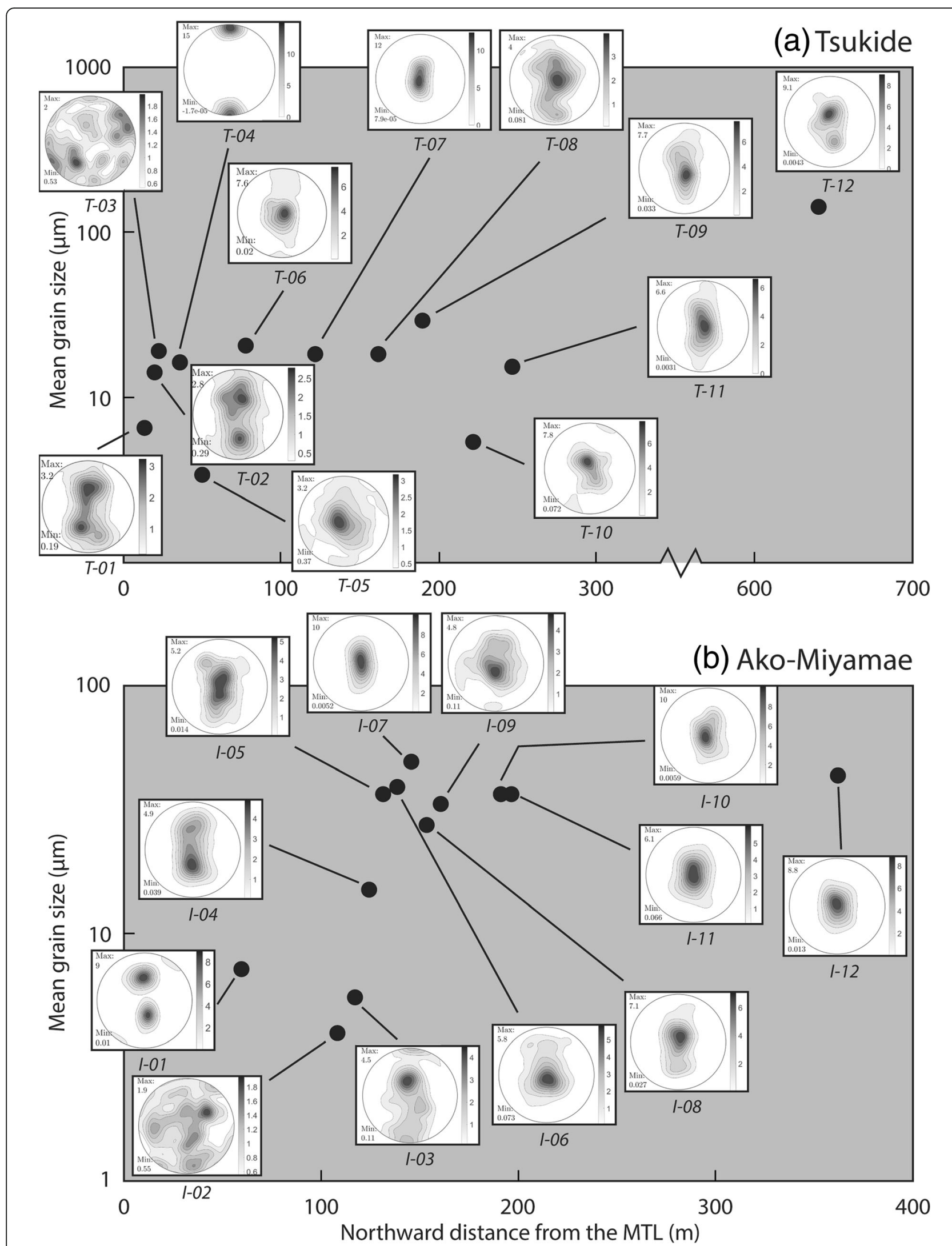

Fig. 9 Variation in quartz recrystalised grain size and [c]-axis fabric with distance from the MTL in the Tsukide (a) and Ako-Miyamae (b) areas 


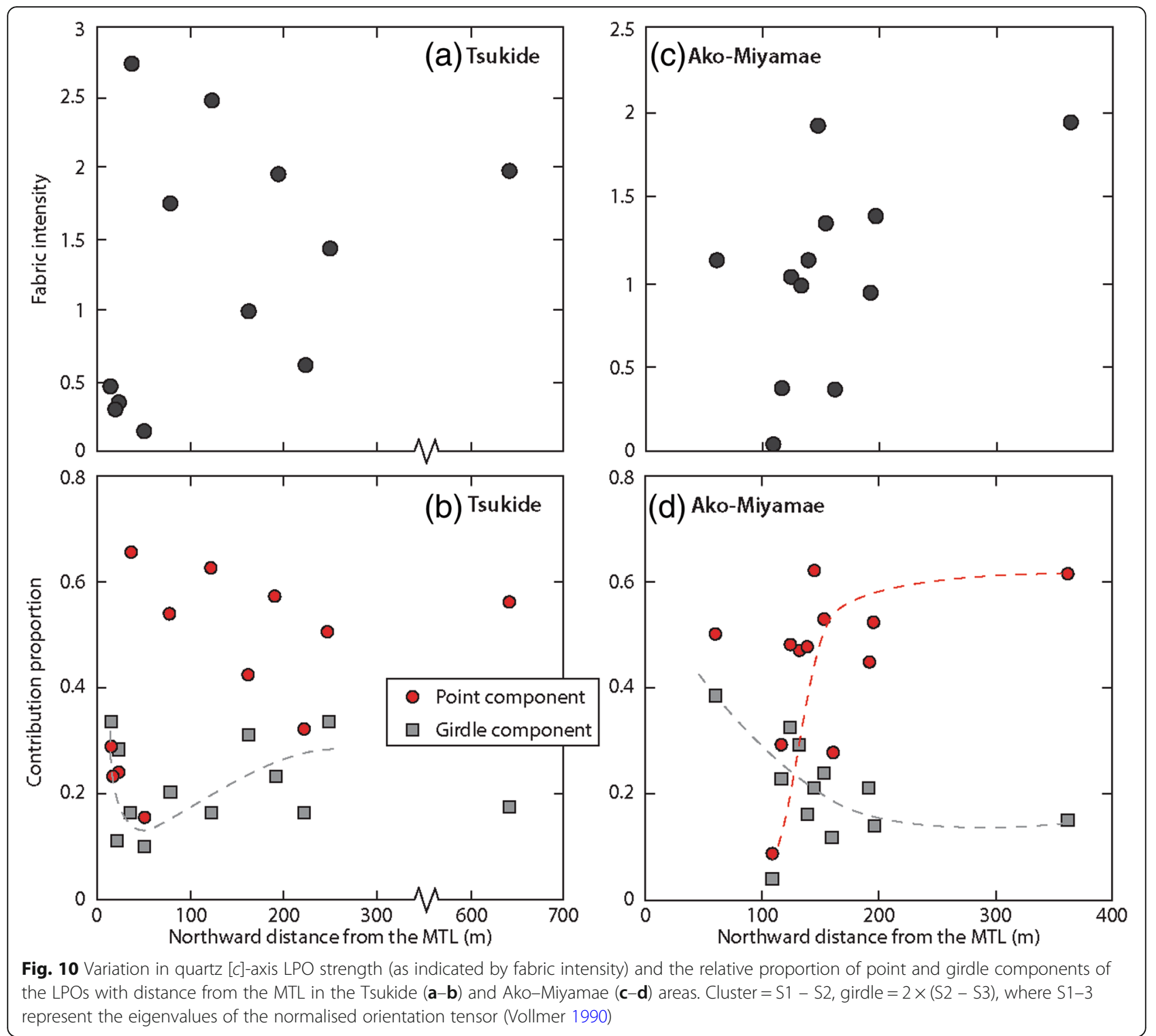

solves the equation of state for water determined by Pitzer and Sterner (1994). We assume that water was present during deformation due to the observation of abundant hydrous phases (e.g., muscovite and chlorite) in the deformed samples. Nabarro-Herring diffusion creep (i.e., deformation accommodated by volume diffusion) was modelled using the flow law of Rutter and Brodie (2004):

$$
\dot{\varepsilon}=\frac{0.4 \sigma e^{\frac{-220000}{R T}}}{d^{2}}
$$

where $\dot{\varepsilon}$ is the strain rate $\left(s^{-1}\right), \sigma$ is differential stress $(\mathrm{MPa})$, and $d$ is the grain size $(\mu \mathrm{m})$. This law is applicable to fluid-absent conditions; however, Rutter and
Brodie (2004) observed no variations in mechanical response associated with water fugacity variations of $\sim 80$ $\mathrm{MPa}$. Pressure-solution creep can be represented by the general equation:

$$
\dot{\varepsilon}=\frac{A V_{\mathrm{m}} c D w \sigma \rho_{\mathrm{f}}}{R T d^{3} \rho_{\mathrm{s}}}
$$

(den Brok 1998) where $A$ is a grain shape constant (44 for spherical grains), $V_{\mathrm{m}}$ is the molar volume of the solid phase, $c$ is the solubility of the solid phase in the fluid, $D$ is the diffusivity of the solid phase along grain boundaries or in grain boundary fluids, $w$ is the width of grain boundaries, $\rho_{\mathrm{f}}$ and $\rho_{\mathrm{s}}$ are the densities of the fluid and solid phases, respectively, and $d$ is the grain size. Behr 
and Platt (2013) compared predicted strain rates from three pressure-solution flow laws with naturally constrained values and determined that the "thin-film" model of Rutter (1976) best matched their observations. We therefore also adopt the thin-film model, which assumes that diffusion occurs across a thin layer of fluid along grain boundaries, and therefore the length scale of diffusion is controlled by the grain size. We calculated $c$ according to Fournier and Potter (1982) and used values of $V_{\mathrm{m}}=2.269 \times 10^{-5} \mathrm{~m}^{3} \mathrm{~mol}^{-1}$ (Berman 1988), $D=$ $4.48 \times 10^{-26} \mathrm{~m}^{2} \mathrm{~s}^{-1}$ (Okudaira et al. 2013), $w=100 \mathrm{~nm}$ (Joesten 1983) $\rho_{\mathrm{f}}=1.083 \mathrm{gmL}^{-1}$ (Burnham 1969), and $\rho_{s}$ $=2.65 \mathrm{gmL}^{-1}$.

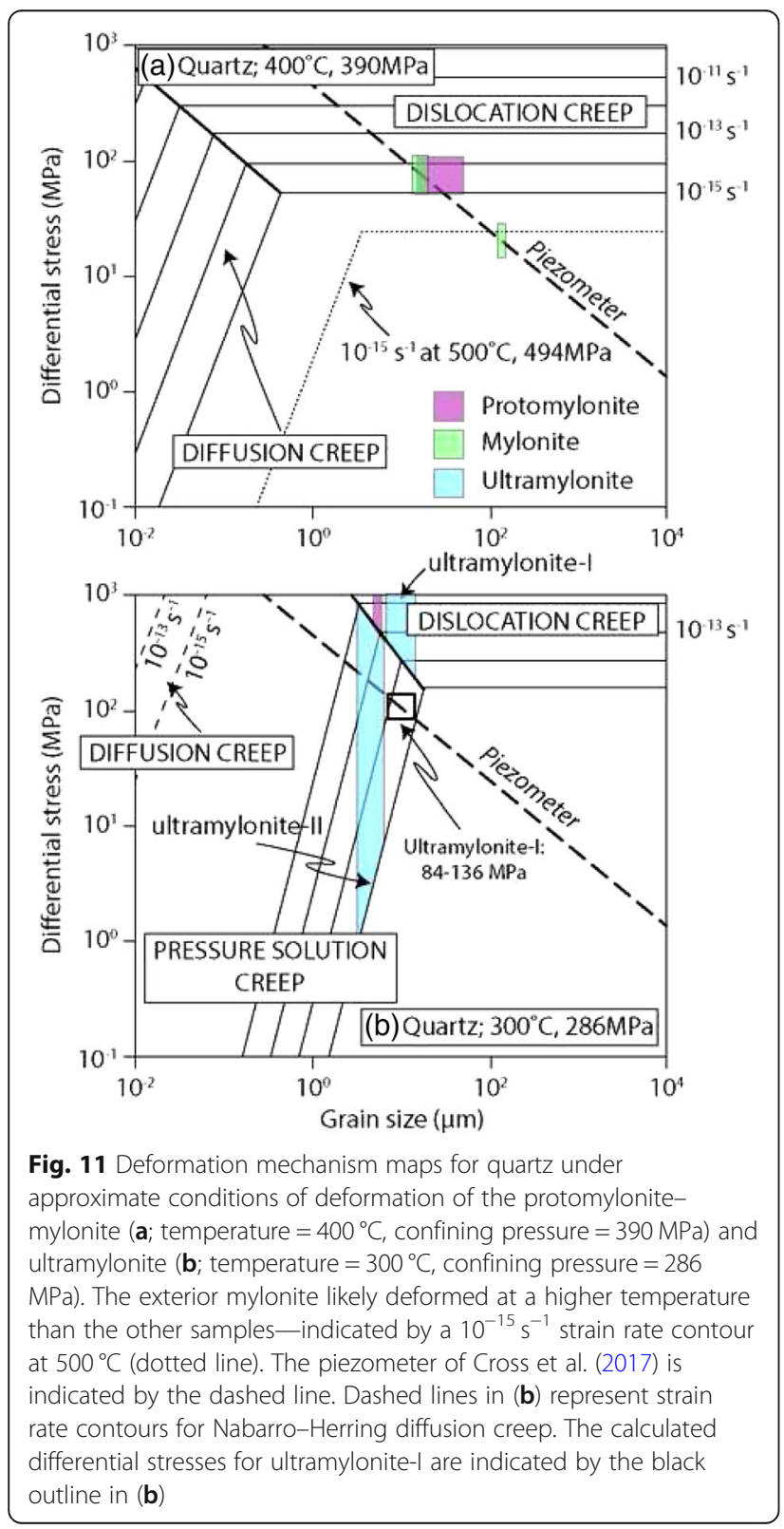

Figure 11 shows two deformation mechanism maps calculated at representative temperatures for the protomylonite/ mylonite and ultramylonite samples $\left(400{ }^{\circ} \mathrm{C}\right.$ and $300^{\circ} \mathrm{C}$, respectively; see previous section) and confining pressures equivalent to a geothermal gradient of $25^{\circ} \mathrm{Ckm}^{-1}$, typical of intraplate continental crust. The piezometer of Cross et al. (2017), which is calibrated for use with EBSD data, is shown on Fig. 11 and can be used to constrain the differential stress during deformation of samples deformed by dislocation creep under steady state. This piezometer uses the following relationship:

$$
D=10^{3.91 \pm 0.41} \times \sigma^{-1.41 \pm 0.21}
$$

where $D$ is the recrystallised grain size and $\sigma$ is the differential stress. The protomylonite samples display a bimodal grain size distribution (i.e., porphyroclasts and recrystallised grains), with most strain likely accommodated within the recrystallised grains. To determine whether these grains achieved steady-state deformation, we constructed grain size histograms for recrystallised grains in all protomylonite samples (e.g., Fig. 12a-d). We included histograms based on area fractions to reduce the bias associated with the large number of small grains that are produced during grain reconstruction. The grains generally display a lognormal distribution (Fig. 12a-d), indicating the achievement of steady-state deformation. However, some variation is observed, with some samples displaying bimodal distributions (e.g., Fig. 12d).

The piezometer suggests that protomylonites and mylonites deformed under stresses of 39.0-81.3 and 70.2-87.8 $\mathrm{MPa}$, respectively. The deformation mechanism map indicates that these samples deformed under a strain rate of between $\sim 10^{-15}$ and $10^{-14} \mathrm{~s}^{-1}$. The exterior mylonite contains coarse grains, indicating deformation under relatively low differential stress $(20.0 \mathrm{MPa})$. As stated above, this sample likely deformed at a higher temperature than the other samples, and therefore a strain rate contour for $500{ }^{\circ} \mathrm{C}$ is included in Fig. 11a.

We observe two types of ultramylonites, differentiated by their quartz LPO. Samples I-01, T-01, and T-03 are fine-grained ultramylonites with $R$-maxima LPOs (ultramylonite-I), interpreted to have deformed by dislocation creep at $\sim 300^{\circ} \mathrm{C}$ under high differential stress $(\sim 84-$ $136 \mathrm{MPa}$; Fig. 11b). One protomylonite sample (T-08) contains a subset of fine matrix grains (mean $=5.3 \mu \mathrm{m}$ ), that also yield $R$-maxima LPOs and are therefore interpreted to have recrystallised under similar conditions as ultramylonite-I. The other examined ultramylonite samples contain fine, equant quartz grains that lack intragranular distortions and have weak to random LPOs (ultramylonite-II). Based on this evidence, we infer that these samples deformed dominantly by grain-size sensitive creep. However, recrystallised grain diameters 

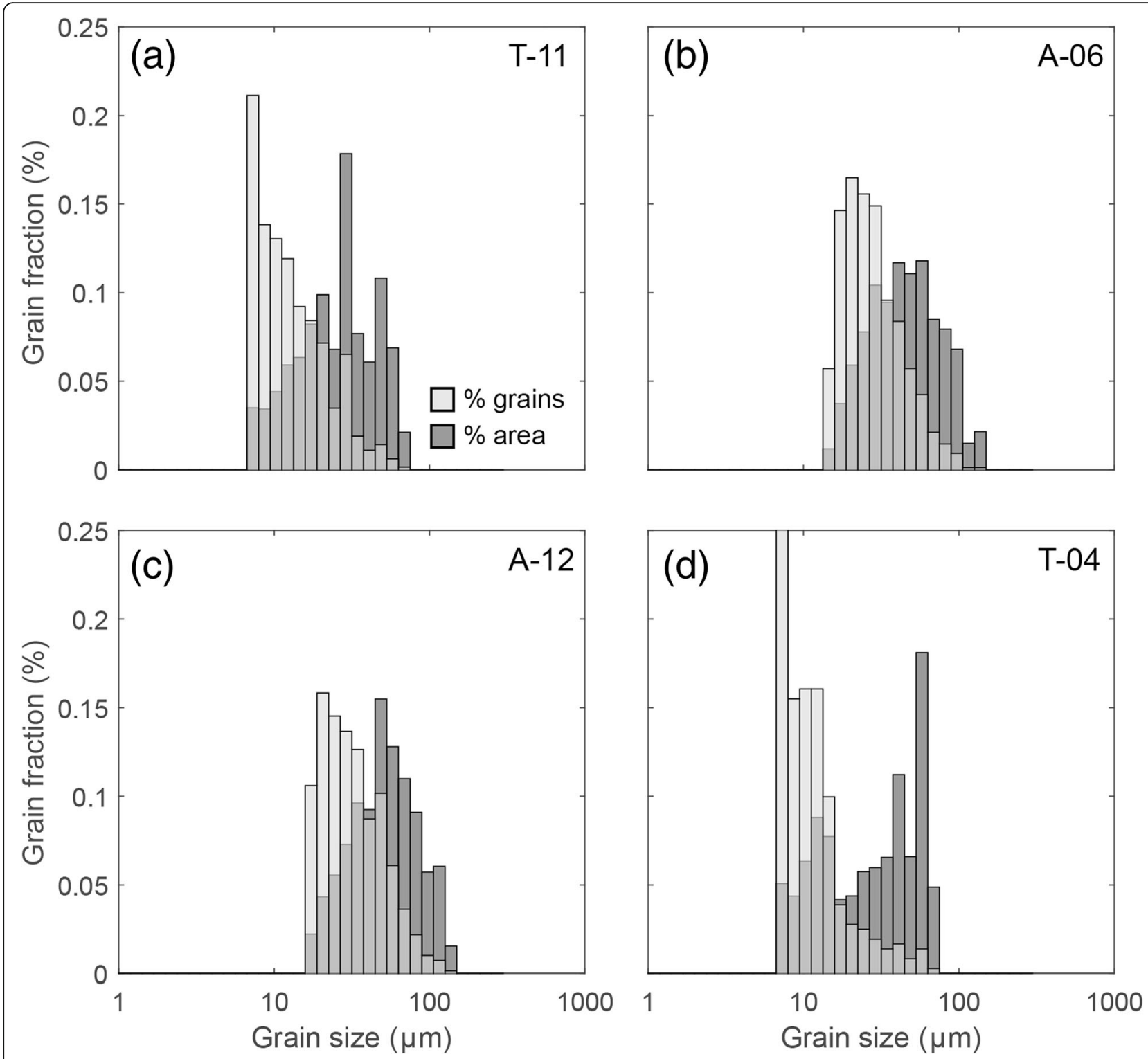

Fig. 12 Grain size distribution histograms for recrystallised grains in protomylonite samples from Tsukide (a and $\mathbf{d}$ ) and Ako-Miyamae (b and $\mathbf{c}$ ). Area fractions are included to account for the bias toward small grains created during grain reconstruction

should be $<0.1 \mu \mathrm{m}$ at $300{ }^{\circ} \mathrm{C}$ for Nabarro-Herring diffusion creep to occur at geological strain rates (dashed lines in Fig. 11b). The abundance of phyllosilicate minerals and pressure-solution seams (Fig. 5e) in these samples suggests deformation under fluid-present conditions, with deformation dominantly accommodated by pressure-solution creep. To test this hypothesis, we plot strain rate contours for pressure-solution creep in Fig. 11b. The grain sizes obtained from ultramylonite-II samples are consistent with pressure-solution creep occurring at geological strain rates $\left(10^{-13}-10^{-15} \mathrm{~s}^{-1}\right.$; Pfiffner and Ramsay 1982) at stresses of between 1 and 385 MPa. Pressure-solution creep is known to result in the elongation of grains through the dissolution of material at high-stress regions and reprecipitation in sites oriented perpendicular to the extension direction (Shimizu 1995). In the Tsukide area, the samples with the weakest quartz $c$-axis fabrics are characterised by elongate grains, consistent with deformation by pressure-solution creep (Fig. 13). However, other mechanisms can result in grain elongation and therefore a precipitation origin must first be verified by other methods, such as cathodoluminescence. A similar trend is not observed in the AkoMiyamae region. It is therefore possible that pressuresolution creep accommodated some deformation; however, we cannot rule out the possibility that some samples deformed via dislocation-accommodated grain-boundary sliding (dis-GBS), as concluded by Okudaira and 


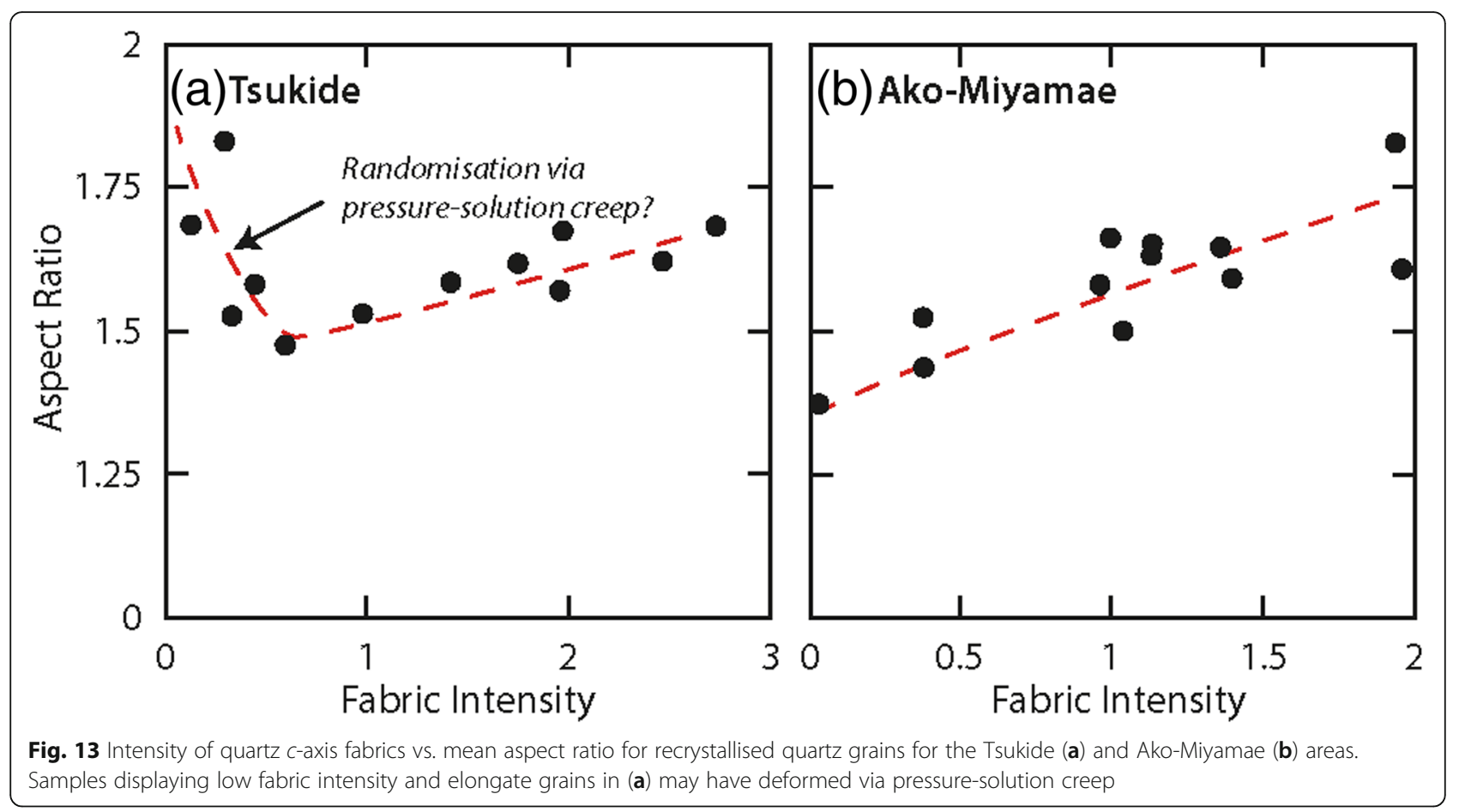

Shigematsu (2012) for ultramylonites in the ITA borehole. Okudaira and Shigematsu (2012) identified intragranular distortions within fine grains, which were not observed in our samples. Further study is required to distinguish between pressure-solution creep and dis-GBS as viable deformation mechanisms.

If pressure-solution creep was activated, it is not possible to determine whether this process was associated with weakening without an independent constraint on the strain rate within the MTL at this time. Pressure-solution creep would require the presence of a fluid, the origin of which could be constrained through oxygen, carbon, and hydrogen stable isotope analysis (e.g., Morrison 1994; Losh 1997; Agosta et al. 2008; Menzies et al. 2014). We currently lack such data and therefore cannot distinguish between metamorphic, magmatic, or meteoric fluids. However, Menzies et al. (2014) and Fujimoto et al. (2002) have shown that meteoric water may penetrate along major faults down to the FVT, due to dilation during ductile deformation or seismicity. In addition, it is possible that the onset of seismicity allowed fluid influx during temporary dilation along the MTL (see Sibson et al. 1988; Sibson 1989, 1992).

\section{Architecture of the MTL}

Figure 14 is a cartoon illustrating the approximate distribution of fault rocks in the hanging wall of the MTL. The observed features can be understood in terms of overprinting relations (e.g., Ichikawa 1980; Takagi 1986; Shimada et al. 1998; Jefferies et al. 2006b; Shigematsu et al. 2012; Okudaira and Shigematsu 2012; Shigematsu et al. 2017). During cooling and/or uplift of the fault zone, the dominant deformation mechanisms and the width of the deforming material varied (Fig. 14). The presence of the exterior mylonite suggests that at high temperature $\left(>500^{\circ} \mathrm{C}\right)$, multiple thick mylonite zones were active, distributed over several hundred meters from the MTL, most of which became abandoned as temperatures decreased. Similar mylonite belts have also been reported from further north of the MTL (1-5 km; Shimada et al. 1998) and may have been active under similar conditions. The exterior mylonite occurs only within the Mitsue granodiorite in the mapped area, suggesting that this lithology may have been more favorable for deformation at this stage in the development of the MTL. Further mapping and lithological data are required to test this hypothesis.

With decreasing temperature $\left(\sim 350^{\circ} \mathrm{C}-450^{\circ} \mathrm{C}\right)$, protomylonite and mylonite in direct proximity to the MTL developed within a broad zone of viscous deformation that likely formed the deep root of a crustal-scale fault zone. Decreasing temperature and increasing stress (inferred from paleopiezometry calculations) resulted in the development of a narrow zone of fine-grained ultramylonites. Influx of fluid caused a transition to grainsize-sensitive creep. It is currently unclear whether the ultramylonites with uniform quartz $c$-axis fabrics (ultramylonite-II) represent a temporal change in deformation mechanism (overprinting), or whether ultramylonite-I and ultramylonite-II 


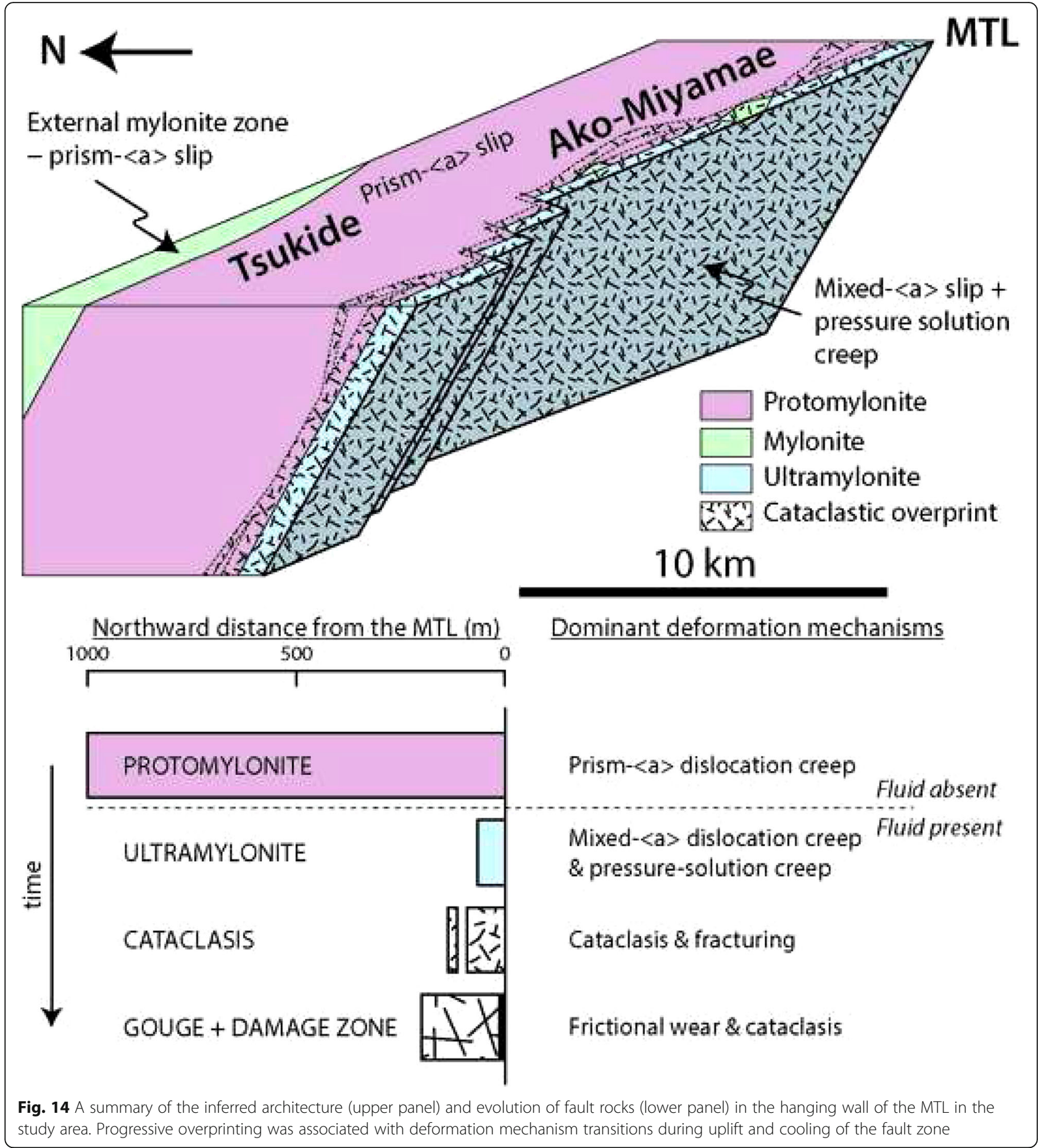

were coeval, and in areas where fluid penetrated the fault zone, pressure-solution creep was activated (spatial variation). Further detailed mapping within the ultramylonite zone is required to distinguish between these two possibilities. However, we currently favor the former hypothesis as samples T-01 and T-02 record transitional fabrics that are consistent with temporal overprinting (i.e., they have undergone limited grainsize-sensitive creep, which has partially randomised their quartz fabrics).

Further cooling prompted a switch to brittle deformation, resulting in the development of a cataclasite zone that was initially localised along the MTL. Development of a phyllosilicate foliation within the cataclasites caused substantial weakening (see Jefferies et al. 2006a, b), preventing the accumulation of significant stress in the 
cataclasites. The folding of cataclastic foliations suggests an overlap between brittle and ductile deformation mechanisms (Fig. 5f). The common observation of veins within the cataclasites suggests that fluid-rock interaction followed fracturing, resulting in the deposition of minerals within fractures, which may have led to a recovery in strength, a process thought to occur during the interseismic period (Tenthorey and Cox 2006). This strengthening resulted in the propagation of the cataclasite zone outward from the MTL, where new, weak foliated cataclasite developed. Thus, intensely crushed rocks (group D) now occur up to $250 \mathrm{~m}$ from the MTL (Table 1).

Deformation under shallow crustal conditions produced fine-grained foliated black fault gouge that occurs locally along the lithological boundary between Ryoke- and Sambagawa-derived rocks. Due to paucity in exposure, it is unclear whether the gouge is variably developed along strike, or whether it only locally traces the lithological boundary and in some areas, migrates into the Sambagawa schist. The latter interpretation is supported by the observations of numerous deformation events within the gouge (Shigematsu et al. 2017), migration of the principle slip zone away from the lithological boundary at Awano-Tabiki (Shigematsu et al. 2017), and a Miocene age from a Tsukide gouge sample (11 Ma, unpublished $\mathrm{K} / \mathrm{Ar}$ data), suggesting the gouge post-dates juxtaposition of the Ryoke and Sambagawa belts.

A wide damage zone (100-300 m) developed during brittle deformation and likely reflects a large displacement across the MTL under upper crustal conditions. Takagi et al. (2012) estimated the thickness of the damage zone to the north of the MTL along the Nishitani river $(\sim 1 \mathrm{~km}$ east of the Ako-Miyamae area) as $\sim 500 \mathrm{~m}$. This discrepancy may be due to the use of a different counting method (scanning polished rock slabs and processing in Adobe Illustrator). In contrast to our measurements, their estimate for the thickness of the damage zone did not use cumulative fractures, as recommended by Choi et al. (2016). However, the difference between our results and those of Takagi et al. (2012) is relatively small, and we infer considerable along-strike variation within the study area. Our results therefore may indicate that the width of the damage zone within the hanging wall of the MTL varies between $\sim 100$ and $500 \mathrm{~m}$. The complex fracture distribution in profile (ii) (Fig. 4) could be interpreted as representing a wide zone of damage associated with the MTL in this location or as evidence for the presence of a minor fault to the north of the MTL. The second interpretation is supported by the observation of cataclasites at $\sim 350 \mathrm{~m}$ from the MTL in this river valley (Fig. 2a). The MTL has undergone multiple reactivation events under brittle conditions (see Shigematsu et al.
2017), all of which may have contributed toward the accumulation of damage surrounding the fault. Furthermore, Takagi et al. (2012) reported X-ray line broadening and crystallinity index data that record a period of cataclasis at deeper crustal levels, which resulted in the generation of dislocation tangles within quartz grains. Therefore, to fully characterise cataclasis in the hanging wall of the MTL, future work is required to relate the observed damage structures to specific deformation events.

\section{Conclusions}

(1) The hanging wall of the MTL in Mie Prefecture preserves mylonitic rocks that deformed under mid-crustal conditions. A broad zone of protomylonite was overprinted by a narrow band of fine-grained ultramylonite.

(2) Deformation by dislocation creep occurred during decreasing temperature and increasing stress, resulting in the localisation of plastic deformation under high stresses in the crust.

(3) Influx of fluid into the fault zone, perhaps facilitated by seismic faulting, promoted a switch to grainsize-sensitive creep, immediately below the frictional-to-viscous transition.

(4) The mylonites were overprinted by brittle cataclasis that developed in a zone similar in width to the ultramylonites, but which propagated into the protomylonite, likely due to strengthening of the cataclasite through vein development.

\section{Abbreviations \\ AR: Aspect ratio; EBSD: Electron backscatter diffraction; LPO: Lattice-preferred orientation; MTL: Median Tectonic Line; SF: Shape factor}

\section{Acknowledgements}

We thank V. Toy for discussions regarding the MTL that contributed to the hypotheses put forward in the manuscript as well as for assistance during EBSD data collection.

\section{Funding}

This research was supported by MEXT KAKENHI grant 15 K21755 to TC, and 26109004 to TC, TT, NS, and KF.

\section{Availability of data and materials}

Please contact author for data requests.

\section{Authors' contributions}

TAC conducted fieldwork, collected samples, performed EBSD analysis, and wrote the manuscript. $\Pi$ helped with fieldwork, EBSD analysis, and helped prepare the manuscript. SA carried out preliminary fieldwork, collected samples, and reviewed the manuscript. TY and JA performed EBSD analysis for some samples and reviewed the manuscript. NS and KF reviewed the manuscript. All authors read and approved the final manuscript.

\section{Competing interests}

The authors declare that they have no competing interests.

\section{Publisher's Note}

Springer Nature remains neutral with regard to jurisdictional claims in published maps and institutional affiliations. 


\section{Author details}

'Department of Natural History Sciences, Hokkaido University, Sapporo 060-0810, Japan. ${ }^{2}$ Department of Earth Science, Tohoku University, Sendai 980-8578, Japan. ${ }^{3}$ Kobelco Research Institute Inc., Kobe 657-0863, Japan. ${ }^{4}$ Department of Earth and Earth and Planetary Systems Science, Hiroshima University, Higashi-Hiroshima 739-8526, Japan. ${ }^{5}$ National Institute of Advanced Industrial Science and Technology, Tsukuba 305-8567, Japan.

${ }^{6}$ Faculty of Education, Tokyo Gakugei University, Tokyo 184-8501, Japan.

Received: 12 June 2018 Accepted: 20 January 2019

Published online: 05 March 2019

\section{References}

Agosta F, Mulch A, Chamberlain P, Aydin A (2008) Geochemical traces of CO2rich fluid flow along normal faults in Central Italy. Geophys I Int 174:758-770

Bachmann F, Hielscher R, Schaeben H (2010) Texture analysis with MTEX-free and open source software toolbox. Solid State Phenom 160:63-68

Behr WM, Platt JP (2013) Rheological evolution of a Mediterranean subduction complex. J Struct Geol 54:136-155

Berman RG (1988) Internally-consistent thermodynamic data for minerals in the system Na2O-K2O-CaO-MgO-FeO-Fe2O3-Al2O3-SiO2-TiO2-H2O-CO2. J Petrol 29:445-522

Bestmann M, Prior DJ (2003) Intragranular dynamic recrystallization in naturally deformed calcite marble: diffusion accommodated grain boundary sliding as a result of subgrain rotation recrystallization. J Struct Geol 25:1597-1613

Brown M (1998) Unpairing metamorphic belts: P-T paths and a tectonic model for the Ryoke Belt, Southwest Japan. J Metamorph Geol 16:3-22

Burnham CW (1969) The specific volume of water in the range 1000 to 8900 bars, $20^{\circ}$ to $900^{\circ} \mathrm{C}$. Am J Sci $267-\mathrm{A}: 70-95$

Caine JS, Evans JP, Forster CB (1996) Fault zone architecture and permeability structure. Geology 24:1025-1028

Chester FM, Evans JP, Biegel RL (1993) Internal structure and weakening mechanisms of the San Andreas fault. J Geophys Res 98:771-786

Choi JH, Edwards P, Ko K, Kim YS (2016) Definition and classification of fault damage zones: a review and a new methodological approach. Earth-Science Rev 152:70-87

Cross AJ, Prior DJ, Stipp M, Kidder S (2017) The recrystallized grain size piezometer for quartz: an EBSD-based calibration. Geophys Res Lett 44:6667-6674

Dallmeyer RD, Takasu A (1991) Middle Paleocene terrane juxtaposition along the Median Tectonic Line, Southwest Japan: evidence from 40Ar/39Ar mineral ages. Tectonophysics 200:281-297

Den Brok SWJ (1998) Effect of microcracking on pressure-solution strain rate: the Gratz grain-boundary model. Geology 26:915-918

Evans JP, Chester FM (1995) Fluid-rock interaction in faults of the San Andreas system: inferences from San Gabriel fault rock geochemistry and microstructures. J Geophys Res 100:13007-13020

Famin V, Raimbourg H, Garcia S et al (2014) Stress rotations and the long-term weakness of the Median Tectonic Line and the Rokko-Awaji segment. Tectonics 33:1900-1919

Faulkner DR, Jackson CAL, Lunn RJ et al (2010) A review of recent developments concerning the structure, mechanics and fluid flow properties of fault zones. J Struct Geol 32:1557-1575

Faulkner DR, Mitchell TM, Rutter EH, Cembrano J (2008) On the structure and mechanical properties of large strike-slip faults. Geol Soc London, Spec Publ 299:139-150

Fournier RO, Potter RW (1982) An equation correlating the solubility of quartz in water from $25^{\circ}$ to $900^{\circ} \mathrm{C}$ at pressures up to 10,000 bars. Geochim Cosmochim Acta 46:1969-1973

Fujimoto K, Ohtani T, Shigematsu N et al (2002) Water-rock interaction observed in the brittle-plastic transition zone. Earth, Planets Sp 54:1127-1132

Fukunari T, Wallis SR (2007) Structural evidence for large-scale top-to-the-north normal displacement along the Median Tectonic Line in Southwest Japan. Island Arc 16:243-261

Hara I, Shyoji K, Sakurai Y et al (1980) Origin of the Median Tectonic Line and its initial shape. Mem Geol Soc Japan 18:27-49

Hayama Y, Yamada T, Ito M et al (1982) Geology of the Ryoke Belt in the eastern Kinki District, Japan: the phase-divisions and the mutual relations of the granitic rocks. J Geol Soc Japan 88:451-466

Hirth G, Teyssier C, Dunlap JW (2001) An evaluation of quartzite flow laws based on comparisons between experimentally and naturally deformed rocks. Int J Earth Sci 90:77-87
Hirth G, Tullis J (1992) Dislocation creep regimes in quartz aggregates. J Struct Geol 14:145-159

Holdsworth RE, Stewart M, Imber J, Strachan RA (2001) The structure and rheological evolution of reactivated continental fault zones: a review and case study. Geol Soc London, Spec Publ 184:115-137

Huzita K (1980) Role of the Median Tectonic Line in the quaternary tectonics of the Japanese islands. Mem Geol Soc Japan 18:129-153

Ichikawa K (1980) Geohistory of the Median Tectonic Line of Southwest Japan. J Geol Soc Japan 18:187-212

lio Y, Sagiya T, Kobayashi Y (2004) Origin of the concentrated deformation zone in the Japanese islands and stress accumulation process of intraplate earthquakes. Earth Planets Sp 56:831-842

Imber J, Holdsworth RE, Butler CA, Lloyd GE (1997) Fault-zone weakening processes along the reactivated Outer Hebrides Fault Zone, Scotland. J Geol Soc Lond 154:105-109

Ishikawa T, Hirono T, Matsuta N et al (2014) Geochemical and mineralogical characteristics of fault gouge in the Median Tectonic Line, Japan: evidence for earthquake slip. Earth, Planets Sp 66:36

Ito T, Ikawa T, Yamakita S, Maeda T (1996) Gently north-dipping Median Tectonic Line (MTL) revealed by recent seismic reflection studies, Southwest Japan. Tectonophysics 264:51-63

Ito T, Kojima Y, Kodaira S et al (2009) Crustal structure of Southwest Japan, revealed by the integrated seismic experiment Southwest Japan 2002. Tectonophysics 472:124-134

Jefferies SP, Holdsworth RE, Shimamoto T et al (2006a) Origin and mechanical significance of foliated cataclastic rocks in the cores of crustal-scale faults: examples from the Median Tectonic Line, Japan. J Geophys Res 111:B12303

Jefferies SP, Holdsworth RE, Wibberley CAJ et al (2006b) The nature and importance of phyllonite development in crustal-scale fault cores: an example from the Median Tectonic Line, Japan. J Struct Geol 28:220-235

Joesten R (1983) Grain growth and grain-boundary diffusion in quartz from the Christmas Mountains (Texas) contact aureole. Am J Sci 283:233-254

Kaneko Y, Takeshita T, Watanabe Y et al (2017) Alteration reaction and mass transfer via fluids with progress of fracturing along the Median Tectonic Line, Mie Prefecture, Southwest Japan. In: Itoh Y (ed) Evolutionary models of convergent margins - origin of their diversity. InTech

Kubota Y, Takeshita T (2008) Paleocene large-scale normal faulting along the Median Tectonic Line, western Shikoku, Japan. Island Arc 17:129-151

Law RD (1990) Crystallographic fabrics: a selective review of their applications to research in structural geology. Geol Soc London, Spec Publ 54:335-352

Lisle RJ (1985) The use of the orientation tensor for the description and statistical testing of fabrics. J Struct Geol 7:115-117

Little TA, Hacker BR, Brownlee SJ, Seward G (2013) Microstructures and quartz lattice-preferred orientations in the eclogite-bearing migmatitic gneisses of the D'Entrecasteaux Islands, Papua New Guinea. Geochemistry, Geophys Geosystems 14:2030-2062

Losh S (1997) Stable isotope and modeling studies of fluid-rock interaction associated with the Snake Range and Mormon Peak detachment faults, Nevada. Bull Geol Soc Am 109:300-323

Mainprice D, Bouchez J-L, Blumenfeld P, Tubía JM (1986) Dominant C slip in naturally deformed quartz: implications for dramatic plastic softening at high temperature. Geology 14:819-822

Mauldon M, Dunne WM, Rohrbaugh MB Jr (2001) Circular scanlines and circular windows: new tools for characterizing the geometry of fracture traces. J Struct Geol 23:247-258

Menzies CD, Teagle DAH, Craw D et al (2014) Incursion of meteoric waters into the ductile regime in an active orogen. Earth Planet Sci Lett 399: $1-13$

Michibayashi K, Masuda T (1993) Shearing during progressive retrogression in granitoids: abrupt grain size reduction of quartz at the plastic-brittle transition for feldspar. J Struct Geol 15:1421-1432

Miyashiro A (1961) Evolution of metamorphic belts. J Petrol 2:277-311

Miyata T (1990) Slump strain indicative of paleoslope in Cretaceous Izumi sedimentary basin along Median tectonic line, Southwest Japan. Geology 18:392-394

Mori H, Wallis S, Fujimoto K, Shigematsu N (2015) Recognition of shear heating on a long-lived major fault using Raman carbonaceous material thermometry: implications for strength and displacement history of the MTL, SW Japan. Island Arc 24:425-446

Morrison J (1994) Meteoric water-rock interaction in the lower plate of the Whipple Mountain metamorphic core complex, California. J Metamorph Geol 12:827-840 
Nakajima T (1994) The Ryoke plutonometamorphic belt: crustal section of the Cretaceous Eurasian continental margin. Lithos 33:51-66

Niwa M, Mizuochi Y, Tanase A (2009) Reconstructing the evolution of fault zone architecture: field-based study of the core region of the Atera Fault, Central Japan. Island Arc 18:577-598

Noda A, Danhara T, Iwano H, Hirata T (2017) LA-ICP-MS U-Pb and fission-track ages of felsic tuff beds of the Takikubo formation, Izumi Group in the Kan-onji district, eastern Shikoku, southwestern Japan. Bull Geol Surv Japan 68:119-130

Okada A (1980) Quaternary faulting along the Median Tectonic Line of Southwest Japan. Mem Geol Soc Japan 18:187-210

Okada A (2012) Research on quaternary faulting history and long-term seismic evaluation of the Median Tectonic Line (MTL) fault zone in Southwest Japan. Quat Res 51:131-150

Okada A, Sangawa A (1978) Fault morphology and quaternary faulting along the Median Tectonic Line in the southern part of the Izumi range. Geogr Rev Jpn 51:385-405

Okudaira T, Bando H, Yoshida K (2013) Grain-boundary diffusion rates inferred from grain-size variations of quartz in metacherts from a contact aureole. Am Mineral 98:680-688

Okudaira T, Beppu Y, Yano R et al (2009) Mid-crustal horizontal shear zone in the forearc region of the mid-cretaceous SW Japan arc, inferred from strain analysis of rocks within the Ryoke metamorphic belt. J Asian Earth Sci 35:34-44

Okudaira T, Shigematsu N (2012) Estimates of stress and strain rate in mylonites based on the boundary between the fields of grain-size sensitive and insensitive creep. J Geophys Res 117:B03210

Okudaira T, Takeshita T, Hara I, Ando J (1995) A new estimate of the conditions for transition from basal to prism [c] slip in naturally deformed quartz. Tectonophysics 250:31-46

Passchier CW, Trouw RAJ (1998) Microtectonics. Springer-Verlag, Berlin Heidelberg, New York

Pfiffner OA, Ramsay JG (1982) Constraints on geological strain rates: arguments from strain states of naturally deformed rocks. J Geophys Res 87:311-321

Pitzer KS, Sterner SM (1994) Equations of state valid continuously from zero to extreme pressures for H2O and CO2. J Chem Phys 101:3111-3116

Rohrbaugh Jr. JB, Dunne WM, Mauldon M (2002) Estimating fracture trace intensity, density, and mean length using circular scan lines and windows. Am Assoc Pet Geol Bull 86:2089-2104

Rowe CD, Griffith WA (2015) Do faults preserve a record of seismic slip: a second opinion. J Struct Geol 78:1-26

Rutter EH (1976) A discussion on natural strain and geological structure - the kinetics of rock deformation by pressure solution. Phil Trans R Soc Lond A 283:203-219

Rutter EH, Brodie KH (2004) Experimental grain size-sensitive flow of hot-pressed Brazilian quartz aggregates. J Struct Geol 26:2011-2023

Sakakibara N (1996) Qualitative estimation of deformation temperature and strain rate from microstructure and lattice preferred orientation in plastically deformed quartz aggregates. J Geol Soc Japan 102:199-210

Sakashima T, Terada K, Takeshita T, Sano Y (2003) Large-scale displacement along the Median Tectonic Line, Japan: evidence from SHRIMP zircon U-Pb dating of granites and gneisses from the South Kitakami and paleo-Ryoke belts. J Asian Earth Sci 21:1019-1039

Sato H, Kato N, Abe S et al (2015) Reactivation of an old plate interface as a strike-slip fault in a slip-partitioned system: Median Tectonic Line, SW Japan. Tectonophysics 644:58-67

Schmid SM, Casey M (1986) Complete fabric analysis of some commonly observed quartz c-axis fabrics. Miner Rock Deform Lab Stud 36:263-286

Scholz CH (1998) Earthquakes and friction laws. Nature 391:37-42

Schulz SE, Evans JP (1998) Spatial variability in microscopic deformation and composition of the Punchbowl fault, southern California: implications for mechanisms, fluid-rock interaction, and fault morphology. Tectonophysics 295 223-244

Shibata K, Nakajima T, Sangawa A et al (1989) K-Ar ages of fault gouges from the Median Tectonic Line in Shikoku. Bull Geol Surv Japan 40:661-671

Shigematsu N, Fujimoto K, Ohtani T et al (2009) Localisation of plastic flow in the mid-crust along a crustal-scale fault: insight from the Hatagawa Fault Zone, NE Japan. J Struct Geol 31:601-614

Shigematsu N, Fujimoto K, Tanaka N et al (2012) Internal structure of the Median Tectonic Line fault zone, SW Japan, revealed by borehole analysis. Tectonophysics 532-535:103-118
Shigematsu N, Kametaka M, Inada N et al (2017) Evolution of the Median Tectonic Line fault zone, SW Japan, during exhumation. Tectonophysics 696697:52-69

Shimada K, Takagi H, Osawa H (1998) Geotectonic evolution in transpressional regime: time and space relationships between mylonitization and folding in the southern Ryoke belt, eastern Kii Peninsula, Southwest Japan. J Geol Soc Japan 104:825-844

Shimizu I (1995) Kinetics of pressure solution creep in quartz : theoretical considerations. Tectonophysics 245:121-134

Sibson RH (1977) Fault rocks and fault mechanisms. J Geol Soc Lond 133:191-213

Sibson RH (1983) Continental fault structure and the shallow earthquake source. J Geol Soc Lond 140:741-767

Sibson RH (1989) High-angle reverse faulting in northern new-Brunswick, Canada, and its implications for fluid pressure levels. J Struct Geol 11:873-877

Sibson RH (1992) Fault-valve behavior and the hydrostatic-lithostatic fluid pressure interface. Earth Sci Rev 32:141-144

Sibson RH, Robert F, Poulsen KH (1988) High-angle reverse faults, fluid-pressure cycling, and mesothermal gold-quartz deposits. Geology 16:551-555

Stipp M, Stünitz H, Heilbronner R, Schmid SM (2002) Dynamic recrystallization of quartz: correlation between natural and experimental conditions. Geol Soc London, Spec Publ 200:171-190

Sugiyama Y (1992) Neotectonics of the forearc zone and the Setouchi Province in Southwest Japan

Suzuki K, Adachi M (1998) Denudation history of the high T/P Ryoke metamorphic belt, Southwest Japan: constraints from CHIME monazite ages of gneisses and granitoids. J Metamorph Geol 16:23-37

Takagi H (1985) Mylonitic rocks of the Ryoke belt in the Kayumi area, eastern part of the Kii peninsula. J Geol Soc Japan 91:637-651

Takagi H (1986) Implications of mylonitic microstructures for the geotectonic evolution of the Median Tectonic Line, Central Japan. J Struct Geol 8:3-14

Takagi H, Takahashi K, Shimada K et al (2012) Integrated estimates of the thickness of the fault damage zone in granitic terrain based on penetrative mesocracks and XRD analyses of quartz. J Struct Geol 35:64-77

Takagi H, Takeshita T, Shibata K et al (1992) Middle Miocene normal faulting along the Tobe thrust in setern Shikoku. J Geol Soc Japan 98:1069-1072

Takasu A, Dallmeyer RD (1990) 40Ar/39Ar mineral age constraints for the tectonothermal evolution of the Sambagawa metamorphic belt, Central Shikoku, Japan: a cretaceous accretionary prism. Tectonophysics 185:111-139

Takeshita T (1993) Deformation of the forearc region and along the Median Tectonic Line in Southwest Japan during the opening of the Japan Sea: a preliminary report. Mem Geol Soc Japan 42:225-244

Takeshita T, El-Fakharani AH (2013) Coupled micro-faulting and pressure solution creep overprinted on quartz schist deformed by intracrystalline plasticity during exhumation of the Sambagawa metamorphic rocks, Southwest Japan. J Struct Geol 46:142-157

Takeshita T, Wenk H-R (1988) Plastic anisotropy and geometrical hardening in quartzites. Tectonophysics 149:345-361

Takeshita T, Wenk H-R, Lebensohn R (1999) Development of preferred orientation and microstructure in sheared quartzite: comparison of natural data and simulated results. Tectonophysics 312:133-155

Tenthorey E, Cox SF (2006) Cohesive strengthening of fault zones during the interseismic period : an experimental study. J Geophys Res 111:B09202

Toy VG, Prior DJ, Norris RJ (2008) Quartz fabrics in the Alpine Fault mylonites: influence of pre-existing preferred orientations on fabric development during progressive uplift. J Struct Geol 30:602-621

Vollmer FW (1990) An application of eigenvalue methods to structural domain analysis. Bull Geol Soc Am 102:786-791

Watkins H, Bond CE, Healy D, Butler RWH (2015) Appraisal of fracture sampling methods and a new workflow tocharacterise heterogeneous fracture networks at outcrop. J Struct Geol 72:67-82

Wibberley CAJ, Shimamoto T (2003) Internal structure and permeability of major strike-slip fault zones: the Median Tectonic Line in Mie Prefecture, Southwest Japan. J Struct Geol 25:59-78

Woodcock NH (1977) Specification of fabric shapes using an eigenvalue method. GSA Bull 88:1231-1236

Yamamoto H (1994) Kinematics of mylonitic rocks along the Median Tectonic Line, Akaishi Range, Central Japan. J Struct Geol 16:61-70 